\title{
The incidence of left-handedness: a meta-analysis
}

\author{
Beatrice M. Seddon and I.C. McManus (1993, unpublished)
}

This paper is probably the most cited of my unpublished manuscripts. It had a chequered publication history, some of which does not reflect well on a prestigious journal, and is probably better not described any further. For various and complex reasons it became difficult to revise the paper, and the manuscript then became somewhat dated, more studies having been published, and the was eventually left in the filing cabinet. However various people knew about it, and it has been cited on a number of occasions, most particularly by myself in the 1991 Ciba Symposium (McManus, 1991), where the two figures were also published in slightly modified form (and where 'incidence' in the title erroneously became 'inheritance').

The version presented here is based on a file on my computer dated 2nd January 1993, although there is also a somewhat modified form dated 11th October 1994. Some minor formatting has been carried out in converting a WordPerfect 5.1 file using an early version of Reference manager to a file in WordPerfect 9 with Reference Manager 9, including setting

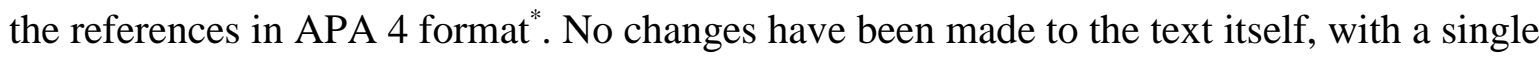
exception where a reference could not be found. The paper has been set in single spacing to help those who wish to print out the document.

I. C. McManus. The inheritance of left-handedness. In: Biological asymmetry and handedness (Ciba foundation symposium 162), edited by G. R. Bock and J. Marsh, Chichester:Wiley, 1991, p. 251-281.

\footnotetext{
* Despite the file being in WordPerfect 5.1, WordPerfect 9 would not read it, and the file had to be ported through Word 97. The effect on the equations in Appendix 1 was particularly dire. Appendices 1 and 2 have therefore been scanned in from a hard copy, and their page numbers are therefore somewhat out of sequence.
} 
The incidence of left-handedness: a meta-analysis.

B eatrice M. Seddon ${ }^{1}$

I.C. M CM anus ${ }^{1,2}$

${ }^{1}$ Department of Psychology
University College L ondon

Gower Street

London WC1E 6BT

${ }^{2}$ Department of Psychiatry

St. M ary's Hospital M edical School

Praed Street

London W 2 1NY 


\begin{abstract}
.
A meta-analysis is reported of 88 studies, examining 100 study populations, in which the handedness of 284665 individuals has been assessed. The overall incidence of left-handedness was $7.78 \%$. The incidence of left-handedness was not related to the method of measurement, or the length or number of response items included in inventories. Study populations with lower response rates and smaller study populations showed some evidence of higher incidences of left-handedness, presumably due to response biasses. There was no evidence that the incidence of left-handedness was related to the year of publication of studies; however the incidence of left-handedness was lower in older subjects and in those from earlier birth cohorts, the two effects not being statistically distinguishable.
\end{abstract}

Information was available from 64 study populations concerning the incidence of left-handedness in males and females; overall $8.52 \%$ of males were left-handed compared with $6.69 \%$ of females, the male incidence being $27.4 \%$ higher than that in females. A Ithough there was some suggestion that the sex difference was greater in larger studies, and in studies whose main purpose was not the study of handedness, these differences were not significant. It is concluded that the size of the sex difference is unrelated to any of the moderator variables we have studied.

It was not possible to carry out a meta-analysis of degree of handedness due to wide-spread differences in the method of reporting of degree of handedness.

W e recommend that future studies of handedness should, as a minimum, use one of three standard methods of assessment, so that comparison of studies is facilitated. 
The majority of humans use their right hand for writing and for carrying out complex manipulative tasks. Humans therefore differ significantly from other mammalian species in which handedness or pawedness has been systematically measured in that although individuals are typically right- or left-handed (or pawed), at the population level approximately $50 \%$ of individuals are right-handed and $50 \%$ are left-handed. Considering studies in which hand or paw preference has been measured directly (and ignoring indirect evidence of behavioural asymmetries (Bradshaw, J. L., 1991), such as in the impala (J arman, P. J ., 1972), or anecdotal reports, as for the left-handedness of polar bears (L opez, B., 1986)), there is no evidence for population-level handedness in mice (Collins, R. L., 1985), rats (K irk, S. A., 1935; U guru-Okorie, D. C. \& A rbuthnott, G. W., 1981), cats (Burgess, J. W. \& Villablanca, J. R., 1986; Cole, J., 1955), and probably monkeys (Brooker, R. J ., L ehmann, R. A. W ., Heimbuch, R. C., \& Kidd, K. K., 1981) and apes (Byrne, R. W . \& Byrne, J . M ., 1991; A nnett, M . \& A nnett, J ., 1991), al though the latter cases are controversial ( $M$ acNeilage, P. F., Studdert-K ennedy, M. G., \& Lindblom, B., 1987; M archant, L. F. \& M cGrew, W. C., 1991; M cGrew, W. C. \& $M$ archant, L. F., 1992). In non-mammalian species, the parrot may be an unusual exception to the above rule (Harris, L. J ., 1989).

Right-handedness is an ancient human characteristic, being recognisable for at least 5000 years in works of art (Coren, S. \& Porac, C., 1977c), where it shows a stable incidence of about 7.4\%; other artefacts, such as bone and antler implements from the N eolithic period, about 7000 years ago, also show evidence of a predominance of righthandedness (Spenneman, D. R., 1984), as do Upper Palaeolithic scrapers from 8 to 35,000 years ago(Semenov, S. A., 1964), and stone tool flakes from 150-200,000 years ago (Cornford, J. M., 1986). Although the evolution of the genus Homo is complex (W ood, B ., 1992a; A ndrews, P., 1992), it does seem that recognisable human remains can first be found in the fossil record some 2.4 M illion years ago (Hill, A., W ard, S., Deino, A ., Curtis, G., \& Drake, R., 1992; W ood, B., 1992b), at a similar time to that at which the first stone tools are also discovered. The stone tools produced in the lower Pleistocene (Toth, N., 1985; L ewin, R., 1986), as well as the patterns of wear on teeth (de Castro, J. M. B., B romage, T. G., \& J alvo, Y . F., 1988; B ahn, P. G., 1989), are both characteristic of those produced by right-handed individuals, suggesting that tool usage was associated with a population level right-handedness. The implication is that the evolution of tool usage and right-handedness may have been causally linked, at a point when man and the apes were diverging.

Functional cerebral lateralisation, with linguistic functions being generally being located in the left hemisphere (Bryden, M. P., 1982), was first clearly recognised by B roca, who, in 1863, described over 25 patients, all of whom suffered from what we would now call aphasia, or lack of speech, and all of whom had suffered from lesions to the left side of the brain (Berker, E. A., B erker, A. H., \& Smith, A., 1986; B roca, P., 1865) (although he had undoubtedly been anticipated by Wigan and Dax - for more detailed historical accounts see (Harrington, A ., 1987; Hécaen, H. \& L anteri-L aura, G., 1977) and (Hécaen, H.\& Dubois, J., 1969)). Since that time it has become apparent that cerebral lateralisation for language is related to handedness, left-handers more often showing non-left sided cerebral dominance for language (Damasio, A. R., 1992; W oods, R. P., Dodrill, C. B., \& Ojemann, G. A ., 1988; B enson, D. F., 1986). A dditionally lefthanders do not show the typical pattern of anatomical asymmetries in the planum temporale (Geschwind, N. \& L evitsky, W., 1968), instead showing a greater degree of symmetry (Stei nmetz, H., V olkmann, J., Jaencke, L., \& Freund, H-J ., 1991).

There is some suggestion that left-handedness may sometimes be the result of cultural (Dawson, J. L. M. B., 1972; Harris, L. J., 1990; Provins, K. A., 1990), learned (Michel, G. F. \& Harkins, D. A., 1985), environmental (Porac, C., Coren, S., \& Searleman, A., 1986c; Porac, C., Izaak, M., \& Rees, L., 1990) or pathological factors 
(Harris, L. J . \& Carlson, D. F., 1988; Soper, H. V . \& Satz, P., 1984; M cM anus, I. C., 1983a), although the evidence in each case is weak, and not supported by evidence of similar incidences of handedness between very different cultures (Connolly, $\mathrm{K}$. \& Bishop, D. V. M ., 1992), the statistical lack of power of studies in small remote cultures to distinguish environmental from genetic factors (M CM anus, I. C. \& Bryden, M. P., 1993a), by the relative unimportance of intra-familial learning processes (L eiber, L. \& A xelrod, S., 1981a), by the almost minimal effects of birth stress upon the incidence of handedness (Searleman, A., Porac, C., \& Coren, S., 1989), and by only 5\% or so of lefthanders showing evidence compatible with pathological origins (Bishop, D. V. M., 1990). There is however clear evidence that left-handedness runs in families ( $M$ cM anus, I. C. \& Bryden, M. P., 1992), and is associated with the handedness of biological rather than adoptive parents (Carter-Saltzmann, L., 1981), implying, at least in part, a genetic origin for the trait. A Ithough many genetic models have been proposed, which have been reviewed el sewhere (M cM anus, I. C. \& Bryden, M. P., 1992), there are at present only two potentially adequate models which can explain data from families, twins, and sex differences, the models of A nnett (A nnett, M ., 1985), and M CM anus (M cM anus, I. C., 1985a; M cM anus, I. C., 1991; M cM anus, I. C. \& Bryden, M . P., 1992). The model s are similar in postulating one allele that produces 'fluctuating asymmetry' (Palmer, A. R. \& Strobeck, C., 1986), a condition in which $50 \%$ of the population are right-handed and $50 \%$ are left-handed (i.e. the situation found in most non-human species), with another allele that produces a directional asymmetry in which the majority of the individuals are right-handed. The models differ in other important respects (M CM anus, I. C., 1985b; M cM anus, I. C., 1985c; M cM anus, I. C., Shergill, S., \& Bryden, M. P., 1993), most notably in their emphasis upon the primary dimension being preference or skill asymmetries, the A nnett model emphasising the primary role of skill differences, whereas the M cM anus model emphasises the importance of preference (M CM anus, I. C., 1991). A lthough the primacy of preference over skill is difficult to assess (Morgan, M. J . \& M cM anus, I. C., 1988), the presence of preference asymmetry in the absence of skill asymmetry in children with autism does suggest that preference is primary ( $\mathrm{M} \mathrm{CM}$ anus, I. C., M urray, B., Doyle, K., \& Baron-Cohen, S., 1992).

Considering the broad pattern of evidence on right-handedness it is possible to make a case for a strong hypothesis which suggests that right-handedness, along with the capacity to make and use tools, to use language, and to show functional and anatomical cerebral specialisation, are characteristics which together are characteristic of humans, and that they are intimately tied together in the divergent evolution of man from the apes (Frost, G. T., 1980; Calvin, W. H., 1982; V arney, N. R. \& Vilensky, J. A ., 1980). This divergence occurred about two and a half million years ago, perhaps as the result of a genetic mutation whereby a gene that once influenced the asymmetry of the viscera instead caused the asymmetric development of the brain, resulting in handedness and language dominance (M cM anus, I. C., 1991). If this hypothesis is correct then the understanding of right-handedness (and by implication, left-handedness also) is of the greatest importance for understanding the origins of humans, and for understanding the relationships between handedness and language lateralisation, and their neurobiological instantiation. L anguage lateralisation is intrinsically difficult to study (and even the best techniques, such as dichotic listening have relatively poor reliability and validity (B ryden, M. P., 1988a; Bryden, M. P., 1988b)). In contrast since handedness is potentially straightforward to assess in large numbers of individuals, using questionnaires or inventories, handedness represents a convenient surrogate for studying the wider aspects of cerebral lateralisation which particularly interest psychologists. A case can therefore be made that finding the gene for handedness will be the key that unlocks the neurobiology of language (M CM anus, I. C., 1991), and that the molecular genetics of cerebral lateralisation is a feasible objective for neuroscience (M cM anus, I. C. \& Bryden, M. P., 1993b). However adequate genetics requires an adequate phenotypics (M cM anus, I. C. \& B ryden, M. P., 1992), and unless the phenotypes of right- and left-handedness are well characterised then the genetics of handedness is likely to be flawed. The present meta-analytic study therefore reviews a large number of studies which have measured the 
incidence of left-handedness in different populations, using different measuring instruments in different ways, to determine how the methods of study and the characteristics of the subjects relate to the incidence of handedness that is found.

The incidence of left-handedness: why does it matter?.

In the majority of the population the right hand is more skilful and is preferred for use in manipulative tasks. The incidence of left-handedness has been measured in many studies, and is typically quoted as "about 10\%", often with a comment to the effect that there seems to be much variation between populations (e.g. (Salmaso, D. \& Longoni, A. M., 1985)), or that the method of classification is arbitrary, due to the phenomenon being distributed along a continuum ( $M$ aehara, $K$. et al., 1988). If a process is genetic then it is important to know whether there is significant variation between populations, either in space or in time. The absence of such variation implies the existence of a balanced polymorphism with strong selective pressures to maintain the two alleles in the genepool; the constraints upon a balanced polymorphism for handedness are discussed el sewhere (M cM anus, I. C., Shergill, S., \& B ryden, M. P., 1993). By contrast, variation between populations may imply the existence of genetic drift, perhaps compounded with sel ective migration (Cavalli-Sforza, L. L. \& Bodmer, W. F., 1971), as seems to be the case with hand-clasping and arm-folding, both of which show strong evidence of a cline across Europe and A sia (M cM anus, I. C. \& M ascie-Taylor, C. G. N., 1979). Previous studies have suggested that the incidence of left-handedness has increased during the present century (Brackenridge, C. J., 1981; L evy, J., 1976). Similarly most genetic studies of handedness have found increased incidences of sinistrality in offspring as compared with parental generations (A shton, G. C., 1982b; M cM anus, I. C., 1985a), al though some of this difference between generations al most certainly reflects reporting biasses due to offspring inaccurately describing the handedness of their parents and grandparents (Porac, C. \& Coren, S., 1979). Over a far longer time-scale, and in contrast to these apparent short-term effects during this century and between generations, the study of hand usage in works of art (Coren, S. \& Porac, C., 1980) found an incidence of about $7.4 \%$ which was unchanged over the past five millennia.

The relationship between handedness and the age of subjects, has become of importance as a result of the hypothesis of $\mathrm{H}$ alpern and Coren that left-handers die at an earlier age than right-handers (Hal pern, D. F. \& Coren, S., 1988b; Coren, S. \& Hal pern, D. F., 1991; Halpern, D. F. \& Coren, S., 1990b), and have a greater number of accidents (Coren, S., 1989). The hypothesis is controversial (Harris, L. J., 1993; Pool, R., 1991), and there have been criticisms of methodology (Charles, D., 1991; Harris, L. J ., 1993; A nderson, M. G., 1989b; R othman, K . J ., 1991), and failures to replicate empirical claims (M arks, J. S. \& Williamson, D. F., 1991; W olf, P. A., D'A gostino, R. B., \& Cobb, J., 1991; Peters, M.\& Perry, R., 1992). Nevertheless there does seem to be general agreement that the incidence of handedness seems to decrease with age and to have increased in recent years (Strang, J., 1991; Dellatolas, G. et al., 1991; Fleminger, J . J., Dalton, E., \& Standage, K. F., 1977; Porac, C., Izaak, M., \& Rees, L., 1990; B rackenridge, C. J., 1981; Levy, J., 1974; B eukelaar, L. J . \& K roonenberg, P. M ., 1986), and that therefore some of the effects reported by $\mathrm{H}$ alpern and Coren may represent secular trends, reflected in cohort effects, rather than effects of differential mortality. In the present study we attempt to disconfound three variables that are potentially confounded: the age of subjects; the year of birth of subjects; and the year in which a study is carried out.

Variation in apparent incidence between populations may also reflect less substantive processes such as different methods of measurement or of different criteria for defining sinistrality. Response biasses on the part of respondents, due to social or other pressures, or due to volunteering behaviour (R osenthal, R. \& R osnow, R. L., 1975) may also produce biassed estimates of the incidence of left-handedness, reflecting the complex social dynamics of participation in psychological experiments (Orne, M. T., 
1962). To take an example, the commonly quoted excess of left-handedness in males (Oldfield, R. C., 1971; L evy, J., 1976) may reflect a tendency of left-handed males to be more likely to respond to questionnaires. Evidence presented elsewhere has suggested that left-handers respond more quickly to a questionnaire which is principally concerned with handedness, and that they have a higher overall response rate, thereby providing potential biasses in assessment of rates (C ornell, E. \& M cM anus, I. C., 1992). Similarly van Eys and McKeever (, 1988a) have shown that subjects' knowledge of an experimenter's interest in lateral isation can modify the results of a dichotic listening task.

In this paper we provide a meta-analysis of a number of studies which have assessed the incidence of left-handedness in populations which were intended to be representative of the general population. In particular we consider the overall population incidence in relation to time and place of measurement, we examine the question of sex differences, and we look at the effects of possible measurement artefacts upon rates in the form of length and type of questionnaires, method of administration, and the nature of the study.

M ethod

The literature on lateralisation is large. M cM anus (, 1986a) estimated that about 5000 papers had been published by 1985; updating that survey suggests that between 1960 and 1989, 6564 papers were cited in P sychological Abstracts under the headings of Cerebral Dominance, Handedness and Lateral Dominance, with 1047 being cited under the heading of Handedness al one. This meta-analysis could not, therefore, hope to provide a complete review of all studies of laterality, and instead we used a sampling strategy that was intended to provide a representative sample of published papers. The complete runs of several journals for the years 1960 to 1989 were assessed and all papers on handedness within that period were included, as also were all papers referred to secondarily by those papers. A dditionally we included all papers on handedness which were included in the reprint collection of one of us (ICM), and we also included the as yet unpublished data from three large population-based studies in which ICM has been involved. This sampling strategy produced a relative dearth of studies published earlier in the century, and therefore we also made a conscious effort to find any papers with estimates of handedness incidences which were published prior to 1960.

The journals Cortex (1964-1989) and Neuropsychologia (1963-1989) were chosen as representative of the neuropsychological literature, B ehaviour G enetics (19771988) was chosen to reflect the genetic literature, Human Biology (1960-1989) to be representative of anthropology, and the British J ournal of P sychology (1965-1989) was chosen as an example of a general interest journal. Papers were chosen for inclusion in the study if they met the following criteria:

i. The study as a whole assessed handedness in at least 100 individuals who were not selected specifically because of their pattern of lateralisation, and also were not some special subset of the general population (such as dyslexics, myasthenics, mathematicians or homosexuals, or those reported as having suffered from 'birth stress', etc.). The randomly selected control groups for specific population subsets were however included in the study. The total population data were also included from studies in which a complete population had been sub-divided for some specific purpose (such as comparing those reporting a history of birth stress with those not reporting such a history).

ii. The study specifically was investigating hand preference and was not only assessing differences in skilled hand performance. Studies were however included if hand preference was assessed directly by asking subjects to perform an unskilled task with one hand or the other, the principal measure being of the hand 
preference for the task.

iii. In general twin studies were excluded from the analysis, since a previous metaanalysis has suggested that different criteria have been applied in assessing the handedness of twins to assessing the handedness of singletons ( $M$ CM anus, I. C., 1980). We did decide to include any twin study in which singleton controls were assessed by identical criteria to those of the twins; in the event, no studies met this criterion.

iv. A number of studies presented their data only in terms of the classification described by A nnett (A nnett, M ., 1967), in which subjects are divided into three handedness groups, left, right and mixed, with the latter category being very broadly defined as all individuals who are not consistently right-handed or consistently left-handed. That criterion results in a far lower incidence of 'left'handedness and a very much higher incidence of 'mixed-handedness' than in other studies (typically of the order of $2-4 \%$ and $25-35 \%$ ). We could find no straightforward way of including this classification within our analysis, and therefore if studies only reported their data in terms of this classification, and did not give sufficient information for us to re-code it in terms of a more conventional criterion, then we excluded it from the analysis.

v. Children were not included in the analysis unless they were at least seven years old (by which time most studies have suggested that the direction of handedness is well established (Hardyck, C., Goldman, R., \& Petrinovich, L., 1975a; M cM anus, I. C. et al., 1988c)). The only exception concerned studies in which data were aggregated across a range of ages (such as "6-12") and in which the vast majority of children were aged over seven (e.g. the studies of Clark (Clark, M . M ., 1957)).

Reasons for rejection of studies.

Studies were rejected for a range of reasons, only a brief summary of which will be given here. $\mathrm{M}$ any studies were excluded as their sample size was too small or because the sample was itself pre-selected on the basis of laterality (e.g. (Liederman, J . \& Healey, J . M., 1986; Tan, L. E., 1983)). Other studies assessed the handedness only of a specialised group such as musicians (Oldfield, R. C., 1969; Byrne, B., 1974), without the inclusion of a control group. A number of studies reported data only in terms of the comparison of skilled performance of right and left hands, without giving preference data per se (e.g.

(Heinlein, A., 1929; Durost, W. N., 1935; Bishop, D. V. M., 1986)). Some twin studies were excluded because of the absence of a singl eton control group (e.g. (Shimizu, A . \& Endo, M., 1983; N eale, M. C., 1988)). Some studies were rejected due to the subjects being less than seven years (Roos, M. M., 1935; M eans, L. W . \& W alters, R. E., 1982; Badian, N. A., 1983)). In some studies although it was apparent that relatively large amounts of data had been collected, these were not unfortunately in a form in which useful information could be extracted; examples include that of Downey (, 1927), in which an eccentric classification scheme was used. In some cases it was apparent that although several separate papers had been published, sometimes by different sets of authors, the studies were neverthel ess re-analyses of a single, often very large, data set; examples include the studies of Nachson \& Denno (, 1986b; Nachson, I. \& Denno, D., 1987), which were excluded in favour of the more comprehensive account of the Philadel phia Collaborative Perinatal Project (Nachson, I., Denno, D., \& A urand, S., 1983); the study of Sanders et al (, 1982a) which was excluded in favour of the study of A shton (, 1982b) of the Hawaii Family Study of Cognition; the study of Teng et al (, 1976a), excluded in favour of their later analysis of data in Teng et al (, 1979a); the study of Hardyck et al (, 1975a), excluded in favour of that of Hardyck et al (, 1976b); and the study of Leiber and Axelrod (, 1981a) excluded in favour of the more comprehensive study of Leiber and Axelrod (, 1981b). 
Sampling frame. As far as was possible from the information given in each of the published studies, the method of recruitment of subjects and the possible bias in their collection was classified as follows. Particular in the case of the assessment of bias it was accepted that there was necessarily a subjective estimate in the assessment, although the two authors usually found themselves in agreement over classification.

Recruitment:

Group 1: Self-selected volunteers, who were responding as a result of their own choice (e.g. Salmaso \& Longoni (, 1983a);

G roup 2: A 'captive' population, representing a complete sample group, such as a whole school, (e.g. Rife (, 1940));

Group 3: A proper random population sample (e.g. Karpinos (, 1953));

G roup 4: Indirect measurement of handedness. In some studies, particularly those interested in familial transmission of handedness, incidences of left-handedness are reported by individuals in their relatives. This group was classified separately since the subjects themselves have never actually been contacted directly by the experimenter.

Possible bias: A subjective assessment of the overall likelihood of bias in the selection of subjects was made by BMS, based on the information given in the paper. Four categories of bias were coded:

Group 1: None; i.e. a completely random sample (e.g. Karpinos (, 1953));

Group 2: Slight (e.g. B eckman et al (, 1962a));

Group 3: Possible (e.g. B ritto et al (, 1989a));

Group 4: Probable (e.g. Birkett (, 1981c)).

Response rate was recorded as a percentage. In those many cases in which it was not available no attempt was made to estimate it, since a pilot study showed that no reasonable estimates could be made in most cases.

Main purpose of study. The main purpose of each study was classified into four groups, according to the range of information being collected, and the extent to which this was principally concerned with handedness or lateralisation. In cases of doubt the data collection process was viewed from the subject's point of view, to assess the extent to which subjects might perceive the study as being principally concerned with handedness rather than with a range of measures. The four categories were:

Group 1: Handedness was the only principal measure (al though possible causal influences upon handedness (such as birth stress) may al so have been measured (e.g J ones and B ell (, 1980a)).

Group 2: Handedness was one of a number of laterality measures collected; otherwise the study was classified as in the previous category; e.g. Searleman, Tweedy and Springer (, 1979b).

G roup 3: One or several other variables were the main rationale for the study, and handedness information was collected as a secondary purpose of the study (e.g. Heim and Watts (, 1976c)).

G roup 4: The study was a large, multivariate study in which many other variables were being measured, and handedness represented a tiny portion of the total data set. A $n$ example is the data collected by Newcombe et al (, 1973a).

Data re-classification. In considering a number of studies it was necessary or useful to re-classify or further process the data from the precise form presented by the original authors, in order to allow maximum comparability between studies. This process took three broad forms: 
i. Extraction of data from graphs. In several studies (Provins, K. A., M ilner, A. D., \& K err, P., 1982c; Silverberg, R., Obler, L. K., \& Gordon, H. W., 1979) a frequency distribution of laterality coefficients was presented and we used that information to calculate the proportion of subjects who had laterality coefficients less than or equal to zero, that precise information not being presented in the original text.

ii. Combination of categories from the original study. Some authors presented tabular data in a more detailed form than was required for this study, and by amalgamating several categories (e.g. weak and strong right-handers ( $L$ ansky, L. M ., Feinstein, H., \& Peterson, J . M ., 1988)) we could reduce the data to a form compatible with other studies. In a few other cases (e.g. (N ewcombe, F. G. et al ., 1975)) the data were presented in a unique and idiosyncratic form, and required a complete re-classification which necessarily involved some minor arbitrary decisions.

iii. Combining sub-populations. Sometimes it was convenient to combine results from a number of sub-populations which were described separately in the original studies, as for instance in combining psychology and engineering students ( $\mathrm{J}$ ones, B . \& B ell, J., 1980a), or of individuals in different geographical areas (A rdila, A. et al., 1989).

Statistical analysis.

The statistical analysis of meta-analytic studies is not entirely uncontroversial; the problems have been reviewed recently (Hunter, J. E. \& Schmidt, F. L., 1990a). A problem with any meta-analysis involving a quarter of a million subjects is that its results may only be significant in a statistical rather than a substantive sense. In this paper we have not depended solely upon formal statistical testing, and instead have also examined the overall patterns of results for relationships that appear theoretically meaningful and appear to be substantial in the sense that effect sizes are large enough to merit concern and interest. However we have however also carried out statistical testing of effects, to determine whether apparent effects of moderator variables is within the bounds of sampling variation. In so doing we are aware of the problem emphasised by Hunter and Schmidt (, 1990a) (p.86) that in examining meta-analytic data for effects of moderator variables then the crucial characteristic is the number of studies (100 in this case) and not the number of subjects (over a quarter of a million). Paradoxically this can mean that the power of meta-analytic studies is surprisingly low, despite their huge subject numbers. In using univariate and multivariate analysis of studies we have followed Glass (, 1977a) in not attempting to take any account of the differing sample sizes in studies (and hence their different sampling errors, and therefore their variance heterogeneity), since, despite the concerns of Hedges and Olkin (, 1985a), we have accepted the argument of Hunter and Schmidt (, 1990a) (p.408) that such problems pale into insignificance in comparison with the problems posed by low power in such studies. In assessing the effects of moderator variables we have therefore used unweighted population estimates from individual studies (i.e. irrespective of study sample size) and compared them by univariate analysis of variance and by multiple regression. In order that the reader can assess whether this may have seriously distorted the results we have presented descriptive statistics which are both weighted and unweighted means across studies.

Results.

A Itogether 88 studies were included in the analysis, which analysed handedness in 100 separate populations, and considered a total of 284665 subjects. Details of the individual studies are shown in table 1.48 (55\%) studies were found by a systematic 
search through the back runs of journals, 30 (34\%) were secondary references, cited in those studies, 10 (12\%) were additional studies found in the reprint collection of one of the authors (ICM ) or were unpublished studies, brief details of which are given in table 1. Some studies (Ramaley, F., 1913; Dawson, J. L. M. B., 1972) included several sets of data that could be regarded as studies of different populations (e.g. because they looked at several distinct age-groups, at different geographical areas, etc.). N ot all information was al ways available for every study, for a variety of reasons.

Of the 88 studies, 5 were published before 1940, 2 in 1940-49, 5 in 1950-59, 4 in 1960-69, 21 in 1970-79, and 48 in 1980-89; an additional three studies were unpublished. The commonest sources of publications were Cortex (24), Neuropsychologia (19), Human Biology (8), Behaviour Genetics (4), British Journal of Psychology (3), and Perceptual and Motor Skills (3), with the remaining published studies coming from 17 different journals and 3 books.

M easurement of handedness.

In 52 studies (60\%) handedness was assessed by some form of written questionnaire, and in 3 studies (3\%) a questionnaire was administered verbally. $11(13 \%)$ studies simply asked the subject whether they were right or left handed, and $13(15 \%)$ studies asked the subjects which hand they used for writing. 7 (8.0\%) studies assessed handedness by observing the subjects' preference for carrying out an unskilled task. In 2 (2\%) studies the method of assessment was not clearly specified. $40(45 \%)$ studies used a specific inventory, which was modified to some extent in $18(42 \%)$ cases. The most popular inventory was the Edinburgh Handedness Inventory (Oldfield, R. C., 1971), being used in 14 studies; 5 studies used the inventory of Raczkowski et al (, 1974), 4 used the Crovitz and Zener (, 1962b) inventory, 4 used the B riggs and Nebes (, 1975b) inventory, 4 used the inventory of Porac and Coren (Porac, C. \& Coren, S., 1981d), 3 used the A nnett (, 1970) inventory, 2 the inventory of Provins et al (, 1982c), 2 the inventory of B ryden (, 1977b), and one each used the inventories of Hatta and Nakatsuka (, 1976d) and Hull (, 1936). Some other studies used their own specific inventories.

A mongst the inventories used, the mean number of questions was 15.3 (median 10.5, mode 10, SD 16.77, range 3 to 82). The individual items on inventories most commonly had 5 response categories (27; 55\% of cases), with 3 items being the next most popular ( 16 cases; 33\%), with 2 items ( 4 cases; $8 \%$ ) and 6 or 7 items ( 1 case each, $2 \%$ ) being much less popular.

The final classification of handedness was into Right and L eft-handedness in 72 (82\%) studies, into Right and Non-right-handedness in 3 studies (3\%), and into Right, $M$ ixed and Left-handedness in $13(15 \%)$ cases. The classification into categories was based on a laterality coefficient or laterality quotient in most cases in which an inventory was used (in almost all cases using some transform of the formula $(R-L) /(R+M+L)$ ). In the 73 studies in which the criterion could be evaluated, $45(62 \%)$ defined lefthandedness as a laterality coefficient or equivalent of less than zero, 19 simply used the writing hand, and 9 used a criterion in which rights-handedness was defined as all inventory items being carried out with the right hand. 15 (17\%) studies mentioned the possibility that some apparently right-handed subjects might be left-handers who had been forced to write with the right hand, and 4 (5\%) studies (e.g. Shimizu and Endo, 1983) explicitly modified their incidence of left-handedness to take this into account.

The incidence of left-handedness.

The incidence of left-handedness will necessarily vary according to the nature of the categories used for describing it, and the criterion applied to it. Table 2 summarises the overall incidence of left-handedness according to whether the study populations distinguished right and left-handedness (R-L), right and non-right-handedness (R-NR) or right, mixed and left-handedness (R-M-L), and in the latter case according to whether 
non-right handedness was defined as left-handers only (i.e. $L /(R+M+L)$ ) or left- and mixed handers combined (i.e. $(L+M) /(R+M+L)$ ). The median and mean rates of nonright-handedness are calculated across study populations, whereas the overall rate of nonrighthandedness is calculated across subjects in the study populations, each subject contributing equally to the final figure; it is therefore weighted so that larger studies contribute more to the estimate than do smaller studies. The overall incidence is probably the best single estimate of the population incidence of left-handedness. Figure 1 shows the incidence of left-handedness in each of the 100 study populations in relation to the specific criterion used for defining left-handedness.

From table 1 it is apparent that the commonest method of assessment, $L /(R+L)$, gives a weighted mean population incidence of $7.68 \%$. Interestingly using a criterion of $L /(R+M+L)$, in which mixed handers or ambidexters are included as a possible response category, gives a very similar weighted mean incidence (8.06\%), in comparison with the more liberal criterion of $(L+M) /(R+M+L)$ which gives a much higher incidence of $15.16 \%$. The rarely used criterion of $R /(R+N R)$ gives a somewhat higher weighted mean incidence, of $11.38 \%$, al though there are only 3 study populations with that criterion. In order to simplify further analyses in this paper we have combined three criteria, and have excluded the fourth criterion of $(L+M) /(R+M+L)$, to give the data shown in the final row of figure 1 . This gives a final overall incidence of $7.78 \%$ for the entire population, based on 284665 subjects.

M ethod of measurement and subjects. Table 3 shows that whether handedness is assessed by questionnaire, performance or a simple question (such as about writing hand or the handedness of the subject) has almost no effect upon the overall incidence of sinistrality $(F(4,93)=.726, N S)$. In studies using a formal questionnaire or inventory, table 4 shows that there is neither an overall relationship $(F(4,47)=122$, NS) nor a linear relationship $(F(1,47)=141, N S)$ between the number of items and the incidence of left-handedness, and table 5 shows that there is no evidence of a relationship between the number of response categories for each item and the overall incidence of sinistrality (Overall: $F(2,46)=.422$, NS; L inear $F(1,46)=.261$, NS).

In the 100 study populations, $26(26 \%)$ used self-selected volunteers, $28(28 \%)$ used a captive whole group of some sort, $39(39 \% \%)$ used a proper random sample and $7(7 \%)$ consisted of left-handedness incidences reported indirectly in others from memory (e.g. parents or grandparents). The sampling method by which the subjects are obtained does seem to have some influence upon the overall incidence of left-handedness (table 6), with self-selected volunteers having a higher incidence of left-handedness than do more systematic methods of obtaining subjects, although the effect is not statistically significant $(F(3,96)=1.37$, NS); indirect reporting of others' handedness is associated with a lower rate of left-handedness, as might be expected from the results of Porac and Coren (, 1981d). O ur subjective assessment of the possible extent of bias occurring during the selection of subjects also shows a clear relationship to the incidence of sinistrality, table 7 showing that biassed studies have a higher incidence of left-handedness than do unbiased studies (Overall $F(3,96)=1.63$; $L$ inear $F(1,96)=3.698, p=.0574$ ). The response rate was known or estimated in 24 study populations, and had a mean of $79 \%$ (SD $27.7 \%$; range 23 - 100\%; median 95\%). Table 8 summarises the relationship between response rate and the incidence of left-handedness; there is some suggestion that lower response rates are associated with higher incidences of left-handedness, as might be expected from the results described earlier of Cornell and M CM anus (, 1992), al though the effect does not show statistical significance (Overall $F(3,27)=.725$; N S: Linear $F(1,27)=.510, N S)$.

Characteristics of study populations. Study populations varied in size, having a mean of 2846 subjects (median $=964, \mathrm{SD}=7655$, range $=95-72238, \mathrm{~N}=100$ ). Table 9 shows that the incidence of left-handedness is lower in the larger study populations, with a particular difference between studies larger than 250 subjects and those less than 250 subjects; nevertheless the linear trend was not significant $(F(1,96)=2.01, N S)$. There was 
also some slight difference in the incidence of left-handedness according to the source of the study; table 10 shows that the study populations obtained through a systematic random search through runs of journals had a slightly higher incidence of left-handedness than the studies obtained as references from those papers, or from a search through the file collection of ICM ; the effect is just at the conventional level of statistical significance $(F(2,97)=3.08, p=.050)$. In part this difference may be explicable by the different sample sizes used in the papers in the different categories, the systematic papers tending to have lower sample sizes (mean $=1658$ ) than those which were obtained as secondary references (mean $=5200$ ), although the personal collection papers had a similar mean size to those in the systematic search (mean=1567).

The main purpose of studies varied, with the principal interest being handedness in $57(57 \%)$ study populations, laterality in general in $20(20 \%)$ studies, other variables in $10(10 \%)$ studies, and being part of a large multivariate study in $13(13 \%)$ study populations. Table 11 shows that the incidence of left handedness was lower in those study populations in which handedness was only one of many variables, as compared with those in which lateralisation was the principal purpose of the study, although the effect was not statistically significant $(F(3,84)=.247$, NS).

Cohort and age effects. Table 12 examines the relationship between the year in which a study population was investigated and the overall incidence of left-handedness; there is some sign that studies carried out later in the century show higher rates of lefthandedness ( $L$ inear: $F(1,96)=5.94, p=.017$ ), although the effect is stronger for the unweighted means than for the (weighted) overall incidences. A similar pattern is seen in table 13 for the relationship between the estimated year of birth of subjects and the overall incidence of left-handedness, although the linear trend across the means is significant $(F(1,73)=6.52, p=.013)$; examining the (weighted) overall incidences suggests only that the incidence appears lower in the few studies with subjects born before 1910 . Table 14 assesses the overall incidence of handedness in relation to the estimated age of the subjects. There is little difference in incidence of left-handedness in subjects aged under 45, but above this age there does appear to be a diminished incidence of lefthandedness. The overall difference between groups is not significant $(F(6,71)=1.486$, NS), al though the linear trend is significant $(F(1,71)=6.20, p=.015)$, without a significant non-linear trend $(F(5,71)=.542, N S)$.

Geographical region. Table 15 summarises the incidence of left-handedness according to the geographical area in which the data were collected. There seems to be little evidence for large differences in incidence according to the geographical area of origin $(F(5,94)=.701, N S)$.

Multivariate analysis of overall incidences. The univariate analyses described above have suggested that several of the moderator variables in tables 3 to 15 have effects upon the overall incidence of left-handedness. In order to assess these effects more clearly we have used a multiple regression analysis in which the dependent variable was the overall incidence of left-handedness in a study, and the independent variables consisted of all those moderator variables in which univariate analyses suggested the possibility of significant effects at least at the 0.2 level (either overall or for the linear trend as appropriate). This resulted in six variables being entered into the analysis which was carried out by a forward stepwise approach;. The variables were: the estimated extent of bias (table 7); the overall size of the study (table 9), expressed as its logarithm to the base 10; whether or not the study was obtained from a systematic search of the literature $(0=$ no; $1=$ Y es; table 10$)$; the year in which the study was carried out (table 12); the year of birth of the subjects (table 13); and the age of the subjects (table 14). All effects (except the dummy variable for systematic search) were expressed as single degrees of freedom representing linear components of the variables. $M$ issing values were replaced by population means. 
Stepwise analysis showed that only two variables were significant predictors of the proportion of left-handers, at the 0.05 level of significance. The first variable entering the equation was the age of the subjects $t(98)=-2.633, p=.0098$, with a slope of $-1.058 \%$ per decade (SE .4018). The second variable entered was the logarithm of the sample size $(t(97)=-2.413, p=.0177)$, with a slope of $-1.942 \%$ per log unit. The only other variables then approaching significance for entry on the next step were the dummy for systematic search $(\mathrm{t}(96)=1.753, \mathrm{p}=.0827)$ and the linear trend of bias $(\mathrm{t}(96)=1.640, \mathrm{p}=.1043)$.

Since age, year of birth and year of study show some degree of multicollinearity, hierarchical analyses were conducted to find whether one was particularly important. $Y$ ear of study did not seem to be of any importance, being non-significant when entered after age $(\mathrm{t}(96)=1.54, \mathrm{p}=.127)$, al though age was still significant when entered after year of study $(\mathrm{t}(96)=-2.57, \mathrm{p}=.0117)$. A ge and year of birth were each significant when entered first $(t(97)=-2.57, p=.0117$ and $t(97)=2.399, p=.0183$ respectively), although neither was significant when entered after the other $(t(96)=-1.476, p=.143$ and $\mathrm{t}(97)=1.031, \mathrm{p}=.305$ respectively). It must be concluded that although age is a better predictor than year of birth, this difference is of only marginal importance, and there is no sense in which age shows a significantly closer relationship than does year of birth. In contrast, year of study is significantly less correlated with the percentage of lefthandedness than is age or year of birth.

Sex differences.

In 65 study populations the sex of the subjects was known, and in 63 study populations both male and female subjects were studied. Figure 2 shows, for each of those study populations, the difference in incidence of left-handedness between males and females expressed as a percentage of the incidence in females (100x(M alesFemales)/Females). It can be seen that in 52 of the 63 study populations there was an excess of male left-handers compared with only 9 studies in which there was an excess of female left-handers, and 2 in which the incidences were the same in the two sexes.

Tables 2 to 15 summarise the overall incidence of left-handedness in males and females and the proportional difference in incidence between the sexes in relation to the background variables in which we have been interested. Only two measures showed any obvious relationship to the size of the sex difference. In table 9 it appears that the sex difference is larger in the studies with the largest sample size, and in table 11 it seems that the sex difference is largest in multivariate studies in which many variables apart from handedness were being assessed. Otherwise the size of the sex difference showed no obvious relationship to the way in which the study had been carried out, the methods of measuring handedness, the year of study or age or year of birth of subjects, or their geographical location. Statistical testing showed no significant effects of any of the moderator variables upon the size of the male-female difference: Table 3: $F(4,56)=1.361$, NS; Table 4: $F(4,25)=2.04$, NS (linear $F(1,25)=2.07$, NS); T able 5: $F(2,27)=1.27$, NS (Linear $F(1,27)=1.40, N S)$; Table 6: $F(3,59)=.907, N S) ;$ Table 7: $F(3,59)=.182$, NS ( L inear $F(1,59)=.381, N S)$; T able 8: $F(3,18)=.191$, NS $(L$ inear $F(1,18)=.388)$; Table 9: $\mathrm{F}(3,59)=.127$ (Linear $\mathrm{F}(1,59)=.004, \mathrm{NS}) ;$ Table 10: $\mathrm{F}(2,60)=.925$, NS; Table 11: $\mathrm{F}(3,59)=.566$, NS; Table 12: $\mathrm{F}(3,59)=.906$, NS ( L inear $\mathrm{F}(1,59)=.36$, NS); Table 13 : $F(4,44)=.655$, NS (Linear $F(1,42)=.359$ NS); Table 14: $F(5,41)=2.52, p=.045$ (Linear $F(1,41)=.017, N S)$; Table 15: $F(4,58)=.482$, NS).

M ultivariate analysis of sex differences. Since none of the moderator variables shown in tables 3-15 had shown significant effects upon the size of the sex difference (and the closest to significance was the linear effect of the number of questionnaire items - table 4 - with $p=.162$ ) then it is not possible that any of them would show significant effects within a stepwise multiple regression. It must be concluded that none of the moderator 
variables were associated with the size of the difference in incidence in males and females.

\section{Discussion.}

This meta-analysis, which has examined the handedness of over a quarter of a million subjects, has found that overall the best estimate of the incidence of lefthandedness is $7.78 \%$, a figure remarkably close to the theoretical estimate derived from genetic studies by M cM anus (, 1985a), and to the value of $7.4 \%$ suggested by Coren and Porac (, 1977c) from their study of works of art over five millennia. Since completing our meta-analysis we have also become aware of the very large study of handedness by Carrothers (, 1947) which looked at 225,000 school-children in M ichigan: it found an overall incidence of left-handedness of $8.2 \%$, with a $34.3 \%$ higher incidence in males than females, both results being remarkably similar to those found in the present study.

A nalysis of the incidence of left-handedness according to the type of measuring instrument suggests that there is little difference between incidences derived from lengthy, detailed inventories and from simple questions about the hand used for writing. The incidence of left-handedness therefore seems to be robust across measurement methods. One possible source of bias concerns the size and the response rate of studies: smaller studies, and those with lower response rates have somewhat higher incidences of left-handedness, possibly because left-handers are more likely to respond in such situations, as has been demonstrated by Cornell and McM anus (, 1992). A similar difference is found in studies in which handedness is manifestly the purpose of the study, as compared with those in which it is merely one variable amongst many others. Stepwise regression suggests that the latter effect is mainly secondary to the effect of study size.

Of particular theoretical interest for understanding the origins of left-handedness is our finding of a lack of obvious difference in the incidence of handedness as a function of the continent in which they live. A genetic theory in which handedness was under strong selective pressure, being maintained by a balanced polymorphism, would expect such a result.

The differences between age groups and birth cohorts are difficult to interpret, in the absence of clear data suggesting that one effect is secondary to the other. This failure probably reflects a poor power of our study, with only 100 studies, to distinguish such effects. Either the age or the year of birth effect could be interpreted as older subjects (who tend to be born earlier), and who have lower incidences of left-handedness, being subject to greater degrees of reporting bias, for one reason or another. A Iternatively there may be genuine differences in handedness between age groups or birth cohorts. Studies comparing the influence of age upon hand preferences for different tasks suggest that some tasks, such as picking up a glass show trends towards greater right-hand usage than do tasks such as writing a letter or cutting with scissors (Porac, C., Izaak, M ., \& Rees, L., 1990), suggesting that social or other pressures may be partly responsible for agerelated changes. Within right-handers there is also evidence that the degree of handedness, as assessed by a peg-board task, becomes greater with age (W eller, M . P. I. $\&$ L atimer-Sayer, D. T., 1985). Taken together these results allow the possibility that apparent age-related or cohort-related changes in incidence of handedness may reflect differences in interpretation of questions, or of different criteria for self-description as right or left-handed. There is a striking absence of adequate longitudinal studies of adult handedness, but we suspect that they would show that the direction of adult handedness is relatively fixed (al though its degree may well change). Taken together we do not feel at present that the effects of age upon handedness are sufficient to support the controversial hypothesis of $\mathrm{Halpern}$ and Coren (, 1990b) that left-handers have an increased mortality compared with right-handers, and hence are less prevalent in older age groups. A principal reason for being sceptical of that result is that in the data of 
Halpern and Coren (, 1988b) there is simply no statistically significant difference in the life-expectancy of the right and left-handers using a conventional t-test (and the meaning of the difference found in their Kolmogorov-Smirnov test then becomes difficult to interpret). Subsequent re-analysis of the Halpern and Coren data by A nderson (, 1989b) has complicated matters by suggesting that longevity may interact with date of birth, there being no overall difference in survival of right and left handers. A t present perhaps the best interpretation would therefore be that older subjects or those from earlier birth cohorts differ from younger subjects in the manner in which they respond to handedness questionnaires, thereby producing some form of response bias.

The sex differences found in this study are of some interest. $M$ any researchers have linked lateralisation and sex differences, although the nature of the relationship is far from clear (see for instance the published commentaries on the paper of M cG lone (, 1980b)). Our meta-analysis leaves little doubt that as measured in most studies of handedness there is an excess of male left-handers over female left-handers. The effect is however relatively small, with about five male left-handers for every four female lefthanders. The lack of any obvious relationship with our assessments of methods of measurement methods, response rates, or the extent of bias in collecting subjects, make it unlikely that the effect is the result of any obvious systematic error in data collection. Similarly the lack of a relationship to the age of subjects, to their date of birth, to the year of the study, or to the geographical location rule out many possible explanations in terms of cultural biasses. A t present we therefore remain agnostic about the origin of these differences, the reality of which seems difficult to dispute. $\mathrm{N}$ evertheless we do note that Porac, Coren and Searleman (, 1983b) (see also Porac, Ress and B uller (, 1990c)) did find that women were significantly more likely than men to report having being forced to change their handedness (principally from left to right); they suggest, perhaps rightly, that this could explain the overall difference in handedness between the sexes.

Taken overall our impression of this large literature (of which we have undoubtedly only sampled a sub-set) is that al though impressive in size and range, with many subjects having been assessed for handedness, the literature is also disappointing in the lack of consistency of methods and approaches between studies, which often precludes any more sophisticated meta-analysis. Data are often poorly presented, with few cross-tabulations, which produces inevitable difficulties in extracting detailed information. The problem is compounded by studies which use unusual or idiosyncratic measurement methods or eccentric methods of classification or reporting which bear little relation to other studies. As an example, we had to discard 15 studies which only reported their data in terms of the right, mixed and left classification of A nnett (, 1967). We do not object to this classification being used as such; it has a theoretical rationale, and it may well be of use. However we feel that reporting only in those terms limits the uses to which the data may be put. We note particularly that A nnett herself (e.g. (, 1973b; , 1979c)) not only reports her data in terms of Right, M ixed and Left but also in terms of the hand used for writing, thereby allowing the data to be included in a meta-analysis such as the present one.

M uch confusion in the literature seems to results from a confusion between the concepts of direction and degree of handedness (M cM anus, I. C., 1983b), which are confounded by studies which merely report the mean laterality score across the whole range of subjects, or which report in terms of three categories such as right, mixed and left in which the mixed category is broadly defined. Frequently the impression is that the term 'mixed' should be replaced by the term 'a mixture', since mixed handers are in reality a mixture of weak right-handers and weak left-handers in indeterminable proportions. The concept of degree of handedness is an important one in laterality, which is only just beginning to be explored (e.g. M cM anus et al (, 1988c), and we are keen to see further analyses of its properties. However in this review we have found ourselves completely unable to carry out any realistic meta-analysis of degree of handedness due to its limited and inadequate reporting in studies, and due to its confounding with other measures. That 
problem would be avoided if studies were to report the results of measures of degree of handedness in a standardised form.

In general we were impressed by the results of the larger studies of handedness simply because the studies had of necessity used fairly straightforward measures of handedness, and had a high response rate because of the method of sampling; examples that particularly come to mind are those of the Scottish scholastic survey (Scottish Council for Research in Education, 1953) in school children, of Komai and Fukuoka (, 1934), also in schoolchildren, and of Karpinos and Grossman (, 1953) in servicemen. We must therefore recommend that in general unless degree of handedness or some detailed analysis of specific items is the particular interest of studies, that simple, easily interpretable questions should be used.

In the interests of further analysis of handedness we therefore recommend that the following methods of measuring and reporting handedness are used, wherever possible. They are described in detail, along with scoring methods, in A ppendix 1.

Recommendations on the measurement of handedness.

a. Handedness should be assessed and reported using one of the following methods:

i. In W estern populations, or in other groups for whom forced changing of writing hand as a result of cultural pressure is now relatively unusual, the best question is "W hich hand do you usually use for writing?". This question avoids many of the ambiguities of asking "A re you right or left-handed?", in which differences of criterion (all / most / some / any tasks left-handed?) can confound results. For a simple incidence study the two replies to the writing hand question,"Right L eft", are sufficient to obtain accurate results ( $M$ ethod $1 . a$ ). If some indication of degree of handedness or of ambidexterity is required then the question can have a fivepoint response scale, "A I ways right / U sually right / Either / U sually left / A I ways left" ( $M$ ethod i.b). The data in table 16, in which such a question was used shows that in fact very few 'either' responses are obtained; however 'usually' replies are fairly frequent and, interestingly, differ in frequency between males and females, being significantly higher in females. The overall incidence of left and right handedness does not differ between the sexes when weak and strong responses are combined. We do not recommend in any circumstances the use of three responses of the form "Right/E ither/L eft", since the method confounds weak handedness with ambidexterity.

ii. In groups where cultural pressure to use the right hand is possible or likely, we recommend that method 1 described above is used (so that full comparative data are available), and that in addition a detailed assessment of cultural pressures to change is also included. Porac et al (, 1986c) have reported a questionnaire which assesses cultural pressures. At present there is little experience of its use, and until more information is available it is difficult to assess it more formally. At present we do not know of any simple form of question which can be used reliably to modify the question of method $i$ to allow correction of handedness for forced change.

iii. If it is desired to measure degree of handedness then the most well-established of the handedness inventories is undoubtedly the E dinburgh Inventory (OIdfield, R. C., 1971), and we recommend that it should be used (M ethod ii). It is not necessarily the very best of measuring instruments, but it does have the advantages of being used frequently (albeit often with some minor modification, as we ourselves recommend). A s was stated by its originator (Oldfield, R. C., 1971):

"Doubtless the inventory is not ideal, but it is simple and provides one quantitative measure of handedness backed by a known distribution of values in a reasonable sized normal population." (emphasis in original). 
A laterality quotient ( $L Q$ ) should be calculated in the conventional manner, and then results presented in terms of particular bands of scores. We recommend that simple left- and right-handedness should be defined as $L Q \leq 0$ and $L Q>0$ respectively. Degree of handedness should always be presented by categorising subjects as weak or strong right-and left-handers. If it is wished to sub-divide categories further then this should be done by dividing these groups into two (to give eight equal categories),etc., so that it is then possible to recombine groups for comparison across studies. In addition means and Sds of laterality quotients can be reported, in which case they should be reported separately for right and lefthanders (defined as $L Q>0$ and $L Q \leq 0$ respectively). The overall mean and $S D$ of the laterality quotient do not provide useful information since they confound direction and degree of handedness.

b. In all studies the incidence of handedness should be reported separately for males and females, using whatever method of assessment has been decided upon.

c. Distributions of laterality coefficients are useful only as an additional form of reporting of incidences; they should not be used as a substitute for the methods described above.

A ppendix 1 sets out in detail the questions that we recommend for assessment of handedness, the calculation of scores, and their methods of reporting. In making these recommendations we do not wish to be prescriptive or to restrict unnecessarily the ways in which handedness may be assessed. However we suggest that as a minimum requirement one or other of the methods described above should normally be included and reported in any study of laterality; other measures may then be included additionally according to the theoretical wishes or the research needs of the investigators. 
Appendix 1: Recommended methods of measuring handedness.

For each method the manner of calculation of the proportion of left-handers $(\mathrm{pL})$ is indicated, along with the method of calculating the proportion of weak left-handers (pWL), weak right-handers (pWR) and weak handedness overall $(\mathrm{pW})$. Whatever method of assessment is used, results of studies should always be reported separately for males and females.

M ethod i.a: "Which hand do you normally use for writing?"

\begin{tabular}{|c|c|}
\hline Responses & Number of replies \\
\hline \hline 'Right' & $\mathrm{R}$ \\
\hline 'Left' & $\mathrm{L}$ \\
\hline
\end{tabular}

Scoring

$$
p L=\frac{L}{R+L}
$$

pW, pWR and pWL cannot be calculated.

M ethod i.b: "Which hand do you normally use for writing?"

\begin{tabular}{||c||c||}
\hline Responses & Number of replies \\
\hline 'Always right' & $\mathrm{R}$ \\
\hline 'Usually right' & $\mathrm{r}$ \\
\hline 'Either' & $\mathrm{e}$ \\
\hline 'Usually left' & $\mathrm{l}$ \\
\hline 'Always left' & $\mathrm{L}$ \\
\hline \hline
\end{tabular}

Scoring All studies should report pL, pWR, PWL and pW. 


$$
\begin{gathered}
p L=\frac{L+I+e}{R+I+e+I+L} \\
p W R=\frac{I}{I+R} \\
p W L=\frac{1}{I+L} \\
p W=\frac{I+e+I}{R+I+e+I+L}
\end{gathered}
$$

Method ii. A recommended modification of the Edinburgh Handedness Inventory (Oldfield, 1971) is presented in Appendix 2. The original questionnaire has been modified principally in that five response categories have been allowed for each of the responses. The questions on eye and foot preference have been omitted from the present version since it is only concerned with handedness.

If it is desired to use a laterality questionnaire with more than the 10 items included in the Edinburgh Inventory then' it is recommended that the 10 items of the Edinburgh should always be included within the longer inventory. Results should be reported separately for the 10 items of the Edinburgh inventory in the method described below, so that comparability is maintained between studies.

More complex inventories can usually be analysed in an analogous fashion to that described below for the Edinburgh inventory. and normally pL, pWR and pWL should be reported for the lengthier questionnaire. If a more detailed subdivision of degree of handedness is required, beyond the categories of weak and strong, it is suggested that further category boundaries should be binary sub-divisions of previous categories i.e. histogram bin divisions should be $0,(-50,0,+50),(-75,-50,-25,0,+25,+50,+75)$, etc, to give $2,4,8$, categories, etc.. Such a division always allows other less detailed classifications to be re-calculated from the data.

Scoring. For an individual subject let $\mathrm{R}, \mathrm{r}, \mathrm{e}, 1$ and $\mathrm{L}$ be the total number of 'Always right', 'Usually right', - 'Either', 'Usually left' and 'Always left' responses (if all questions have been answered, R+r+e+l+L=10). All studies should report pL, pWL and pWR; other measures are optional. 
For each subject calculate a laterality quotient, LQ:

$$
L Q=\frac{100 \cdot\left(R+\frac{I}{2}-\frac{I}{2}-L\right)}{R+I+e+I+L}
$$

Let $n(. .$.$) be the total number of subjects satisfying a condition, and let \mathrm{N}$ be the total number of subjects, then:

$$
\begin{gathered}
p L=\frac{n(L Q \leq 0)}{N} \\
p W R=\frac{n(50>L Q>0)}{n(L Q>0)} \\
p W L=\frac{n(-50>L Q>0)}{n(L Q>0)} \\
p W=\frac{n(-50<L Q<50)}{N}
\end{gathered}
$$

If means and standard deviations of the LQ are to reported then they should be given separately for righthanders $(\mathrm{LQ}>0)$ and for left-handers $(\mathrm{LQ} \leq 0)$.

If the continuum of laterality scores is to be further sub-divided then it can be done as in the text, into 8 , 16 classes, etc.. 
A ppendix 2: Recommended handedness inventory.

\section{Handedness inventory}

Please indicate your preferences in the use of a hand for the following activities by putting a tick in the appropriate column.

Some of the activities require both hands. In these cases the part of the task,or object, for which hand preference is wanted is indicated in brackets.

Please try to answer all the questions and only leave a blank if you have no experience at all of the object or task.

\begin{tabular}{|r||l|l|l|l|l||}
\hline & $\begin{array}{c}\text { Always } \\
\text { Left }\end{array}$ & $\begin{array}{c}\text { Usually } \\
\text { Left }\end{array}$ & Either & $\begin{array}{c}\text { Usually } \\
\text { Right }\end{array}$ & $\begin{array}{c}\text { Alwa } \\
\text { s Lefi }\end{array}$ \\
\hline 1. Writing & & & & & \\
\hline 2. Drawing & & & & & \\
\hline 3. Throwing & I & & \multicolumn{2}{|c||}{ I } \\
\hline 4. Scissors & & & & & \\
\hline 5. Toothbrush & & & & & \\
\hline 6. Knife (without fork) & & & & & \\
\hline 7. Spoon & & & & & \\
\hline $\begin{array}{r}\text { 8. Broom (upper hand) } \\
\text { 9. Striking match } \\
\text { (holding the match) }\end{array}$ & & & & & \\
\hline $\begin{array}{r}\text { 10. Opening box } \\
\text { (holding the lid) }\end{array}$ & & & & & \\
\hline
\end{tabular}


Table 1: A summary of the studies included in the meta-analysis.

\begin{tabular}{|c|c|c|c|c|c|c|c|c|c|c|c|}
\hline Study & Subjects & How found & $\begin{array}{l}\text { Estimated } \\
\text { bias }\end{array}$ & $\begin{array}{l}\text { Respons } \\
\text { e rate }\end{array}$ & $\begin{array}{l}\text { A ssessment } \\
\text { method }\end{array}$ & $\begin{array}{l}\text { Handedness } \\
\text { criterion }\end{array}$ & $\begin{array}{l}\text { Final } \\
\text { category }\end{array}$ & Sub-groups & $\begin{array}{l}\text { \%L eft- } \\
\text { handed: } \\
\text { Total }\end{array}$ & M ales & Females \\
\hline $\begin{array}{c}\text { Ramaley, } 1913 \\
\text { (Ramaley, F., 1913) }\end{array}$ & $\begin{array}{l}1130 \text { A merican } \\
\text { students; } \\
610 \text { parents }\end{array}$ & $\begin{array}{l}\text { Students in } \\
\text { lectures; parents } \\
\text { by questionnaire }\end{array}$ & 3 & - & $\begin{array}{l}\text { 'A re you } \\
\text { R/L } \\
\text { handed?' }\end{array}$ & $\begin{array}{l}\text { A nswer to } \\
\text { question }\end{array}$ & $R-L$ & $\begin{array}{l}\text { Parents } \\
\text { Offspring }\end{array}$ & $\begin{array}{l}8.0 \\
15.7\end{array}$ & - & $\begin{array}{l}- \\
-\end{array}$ \\
\hline $\begin{array}{c}\text { Smith, } 1917 \text { (Smith, L. } \\
\text { G., 1917) }\end{array}$ & $\begin{array}{l}2055 \text { A merican } \\
\text { school children }\end{array}$ & $\begin{array}{l}\text { Total population } \\
\text { of } 3 \text { schools }\end{array}$ & 2 & $100 \%$ & $\begin{array}{l}\text { Not } \\
\text { specified }\end{array}$ & - & $R-L$ & - & 5.0 & 5.5 & 4.5 \\
\hline $\begin{array}{c}\text { Chamberlain, } 1928 \\
\text { (Chamberlain, H. D., } \\
\text { 1928) }\end{array}$ & $\begin{array}{l}7714 \text { A merican } \\
\text { children; } \\
4354 \text { parents }\end{array}$ & $\begin{array}{l}\text { Complete } 1927 \\
\text { Freshman class } \\
\text { at Ohio State } \\
\text { University, and } \\
\text { families }\end{array}$ & 2 & $100 \%$ & $\begin{array}{l}\text { 'A re you } \\
\text { R/L } \\
\text { handed?' }\end{array}$ & $\begin{array}{l}\text { A nswer to } \\
\text { question }\end{array}$ & $R-L$ & $\begin{array}{l}\text { Parents } \\
\text { Offspring }\end{array}$ & $\begin{array}{l}3.6 \\
4.8\end{array}$ & $\begin{array}{l}4.1 \\
5.3\end{array}$ & $\begin{array}{l}2.9 \\
3.8\end{array}$ \\
\hline $\begin{array}{c}\text { Koch et al.1933 (Koch, } \\
\text { H. L. et al., 1933) }\end{array}$ & $\begin{array}{l}201 \text { A merican } \\
\text { students }\end{array}$ & $\begin{array}{l}\text { Random sample } \\
\text { form } 1928 \text { year } \\
\text { at Texas } \\
\text { University }\end{array}$ & 2 & - & $\begin{array}{l}\text { Written } \\
\text { questionnair } \\
\text { e }\end{array}$ & $\mathrm{LQ}<0$ & $R-L$ & - & 7.6 & - & - \\
\hline $\begin{array}{l}\text { Komai and Fukuoka, } \\
1934 \text { (K omai, T.\& } \\
\text { Fukuoka, G., 1934) } \\
\end{array}$ & $\begin{array}{l}16947 \text { J apanese } \\
\text { children }\end{array}$ & $\begin{array}{l}\text { Grades } 1-8 \text { of } 20 \\
\text { primary schools }\end{array}$ & 2 & - & $\begin{array}{l}\text { Written } \\
\text { questionnair } \\
\mathrm{e}\end{array}$ & A ny items $L$ & $R-L$ & - & 11.5 & 12.3 & 10.6 \\
\hline $\begin{array}{c}\text { Rife, } 1940 \text { (Rife, D. C., } \\
1940)\end{array}$ & $\begin{array}{l}3542 \text { A merican } \\
\text { children and } \\
\text { adults }\end{array}$ & $\begin{array}{l}\text { Captive whole } \\
\text { group of students } \\
\text { and their families }\end{array}$ & 2 & - & $\begin{array}{l}\text { Written } \\
\text { questionnair } \\
\text { e }\end{array}$ & A ny items $L$ & $R-L$ & - & 7.5 & - & - \\
\hline $\begin{array}{c}\text { Rife and Schonfield, } \\
1944 \text { (Rife, D. C. \& } \\
\text { Schonfield, M. D., } \\
\text { 1944) }\end{array}$ & $\begin{array}{l}325 \text { A merican } \\
\text { students }\end{array}$ & $\begin{array}{l}\text { Self-selected } \\
\text { volunteers }\end{array}$ & 2 & - & $\begin{array}{l}\text { Written } \\
\text { questionnair } \\
\text { e }\end{array}$ & A ny items $L$ & $R-L$ & - & 11.7 & - & - \\
\hline $\begin{array}{c}\text { K arpinos and } \\
\text { Grossman, 1953 } \\
(\text { K arpinos, B. D. \& } \\
\text { Grossman, H. A., 1953) }\end{array}$ & $\begin{array}{l}12159 \text { A merican } \\
\text { men }\end{array}$ & $\begin{array}{l}\text { Random sample; } \\
\text { all army recruits } \\
\text { (accepted and } \\
\text { rejected) on 18th, } \\
\text { 28th and 30th } \\
\text { J une } 1952\end{array}$ & 1 & $100 \%$ & $\begin{array}{l}\text { 'A re you } \\
\text { R/L } \\
\text { handed?' }\end{array}$ & $\begin{array}{l}\text { A nswer to } \\
\text { question }\end{array}$ & $R-L$ & - & 8.8 & 8.8 & - \\
\hline $\begin{array}{l}\text { Scottish Council for } \\
\text { Research in Education, } \\
\text { 1953; see Clark, 1957 }\end{array}$ & $\begin{array}{l}72238 \text { Scottish } \\
\text { school children }\end{array}$ & $\begin{array}{l}\text { Complete } \\
\text { population; all } \\
10-11 \text { year old }\end{array}$ & 1 & $100 \%$ & $\begin{array}{l}\text { Writing } \\
\text { hand }\end{array}$ & W riting hand & $R-L$ & - & 5.6 & 6.7 & 4.4 \\
\hline
\end{tabular}

(Table continued) 


\begin{tabular}{|c|c|c|c|c|c|c|c|c|c|c|c|}
\hline Study & Subjects & How found & $\begin{array}{l}\text { Estimated } \\
\text { bias }\end{array}$ & $\begin{array}{c}\text { Respons } \\
\text { e rate }\end{array}$ & $\begin{array}{l}\text { A ssessment } \\
\text { method }\end{array}$ & $\begin{array}{l}\text { Handedness } \\
\text { criterion }\end{array}$ & $\begin{array}{l}\text { Final } \\
\text { category }\end{array}$ & Sub-groups & $\begin{array}{l}\text { \%L eft- } \\
\text { handed: } \\
\text { Total }\end{array}$ & Males & Females \\
\hline (Clark, M. M., 1957) & & $\begin{array}{l}\text { children in } \\
\text { Scotland in } 1953\end{array}$ & & & & & & & & & \\
\hline $\begin{array}{c}\text { Clark, } 1957 \text { (Clark, M. } \\
\text { M.., 1957) }\end{array}$ & $\begin{array}{l}5790 \text { Scottish } \\
\text { school children }\end{array}$ & $\begin{array}{l}\text { Captive whole } \\
\text { group; } 8 \\
\text { Glasgow schools }\end{array}$ & 1 & $100 \%$ & $\begin{array}{l}\text { Writing } \\
\text { hand }\end{array}$ & W riting hand & $R-L$ & - & 7.0 & 8.0 & 5.9 \\
\hline $\begin{array}{l}\text { M errell, } 1957 \text { (M errell, } \\
\text { D. J., 1957) }\end{array}$ & $\begin{array}{l}123 \text { A merican } \\
\text { adults }\end{array}$ & $\begin{array}{l}\text { Randomly } \\
\text { selected } \\
\text { university } \\
\text { students } \\
\end{array}$ & 3 & - & $\begin{array}{l}\text { Writing } \\
\text { hand }\end{array}$ & W riting hand & $R-L$ & - & 4.1 & 4.2 & 3.9 \\
\hline $\begin{array}{c}\text { Falek, } 1959 \text { (Falek, A., } \\
1959)\end{array}$ & $\begin{array}{l}10236 \text { A merican } \\
\text { adults }\end{array}$ & $\begin{array}{l}\text { Parents of } \\
\text { children at } 6 \\
\text { randomly } \\
\text { selected schools } \\
\end{array}$ & 1 & $47 \%$ & $\begin{array}{l}\text { Written } \\
\text { questionnair } \\
\text { e }\end{array}$ & $\mathrm{LQ}<0$ & $R-L$ & - & 3.5 & 3.9 & 3.1 \\
\hline $\begin{array}{c}\text { Collins, } 1961 \text { (Collins, } \\
\text { E. H., 1961) }\end{array}$ & $\begin{array}{l}943 \text { male } \\
\text { A merican } \\
\text { students }\end{array}$ & $\begin{array}{l}\text { Captive whole } \\
\text { group; Dental } \\
\text { and medical } \\
\text { students at } \\
\text { University of } \\
\text { Illinois, 1954-59 } \\
\end{array}$ & 3 & - & $\begin{array}{l}\text { Written } \\
\text { questionnair } \\
\text { e }\end{array}$ & A ny item L & $R-M-L$ & $\stackrel{L}{L+M}$ & $\begin{array}{c}9.8 \\
22.9\end{array}$ & $\begin{array}{c}9.8 \\
22.9\end{array}$ & $\begin{array}{l}- \\
-\end{array}$ \\
\hline $\begin{array}{l}\text { B eckman and Elston, } \\
1962 \text { (B eckman, L. \& } \\
\text { Elston, R., 1962a) }\end{array}$ & $\begin{array}{l}981 \text { Swedish } \\
\text { adults }\end{array}$ & Random sample & 2 & - & $\begin{array}{l}\text { Not } \\
\text { specified }\end{array}$ & - & $R-L$ & - & 5.4 & 5.1 & 5.7 \\
\hline $\begin{array}{c}\text { Crovitz and Zener, } \\
1962 \text { (Crovitz, H.F. \& } \\
\text { Zener, K., 1962b) }\end{array}$ & $\begin{array}{l}1569 \text { A merican } \\
\text { students }\end{array}$ & $\begin{array}{l}\text { Self-selected } \\
\text { volunteers }\end{array}$ & 3 & - & $\begin{array}{l}\text { Written } \\
\text { questionnair } \\
\text { e }\end{array}$ & L aterality score & $R-L$ & - & 10.7 & 11.2 & 10.2 \\
\hline $\begin{array}{c}\text { Pelecanos, } 1969 \\
\text { (Pelecanos, M., 1969) }\end{array}$ & $\begin{array}{l}2144 \text { Greek } \\
\text { children }\end{array}$ & $\begin{array}{l}\text { From } 9 \text { randomly } \\
\text { selected primary } \\
\text { schools in } \\
\text { Thessal oniki }\end{array}$ & 2 & - & $\begin{array}{l}\text { Performance } \\
\text { of } 5 \text { tasks } \\
\text { (e.g. cutting, } \\
\text { catching) }\end{array}$ & A ny item $L$ & $R-L$ & - & 10.4 & 11.2 & 9.3 \\
\hline $\begin{array}{c}\text { A nnett, } 1970 \text { (A nnett, } \\
\text { M., 1970) }\end{array}$ & $\begin{array}{l}2322 \text { B ritish } \\
\text { students and } \\
\text { adults }\end{array}$ & $\begin{array}{l}\text { Random sample; } \\
\text { university } \\
\text { students and } \\
\text { servicemen }\end{array}$ & 3 & - & $\begin{array}{l}\text { Written } \\
\text { questionnair } \\
\text { e }\end{array}$ & - & $R-M-L$ & $\stackrel{L}{L+M}$ & $\begin{array}{c}4.3 \\
31.7\end{array}$ & $\begin{array}{l}- \\
-\end{array}$ & $\begin{array}{l}- \\
-\end{array}$ \\
\hline $\begin{array}{c}\text { Oldfield, } 1971 \\
\text { (Oldfield, R. C., 1971) }\end{array}$ & $\begin{array}{l}1109 \text { B ritish } \\
\text { students }\end{array}$ & $\begin{array}{l}\text { Self-selected } \\
\text { volunteers; first } \\
\text { year students at } \\
\text { several B ritish }\end{array}$ & 2 & - & $\begin{array}{l}\text { Written } \\
\text { questionnair } \\
\text { e }\end{array}$ & $L Q<0$ & $R-L$ & - & 7.4 & 10.0 & 5.9 \\
\hline
\end{tabular}

(Table continued) 


\begin{tabular}{|c|c|c|c|c|c|c|c|c|c|c|c|}
\hline Study & Subjects & How found & $\begin{array}{l}\text { Estimated } \\
\text { bias }\end{array}$ & $\begin{array}{c}\text { Respons } \\
\text { e rate }\end{array}$ & $\begin{array}{l}\text { A ssessment } \\
\text { method }\end{array}$ & $\begin{array}{l}\text { Handedness } \\
\text { criterion }\end{array}$ & $\begin{array}{c}\text { Final } \\
\text { category }\end{array}$ & Sub-groups & $\begin{array}{l}\text { \%L eft- } \\
\text { handed: } \\
\text { Total }\end{array}$ & Males & Females \\
\hline & & universities & & & & & & & & & \\
\hline $\begin{array}{c}\text { Dawson, } 1972 \\
\text { (Dawson, J.L. M. M., } \\
\text { 1972) }\end{array}$ & $\begin{array}{l}95 \text { A borigines; } \\
204 \text { Sierra L eone } \\
\text { Temnes }\end{array}$ & R andom sample & 3 & - & $\begin{array}{l}\text { Performance } \\
\text { of } 3 \text { tasks } \\
\text { (writing, } \\
\text { receiving } \\
\text { object, } \\
\text { cutting) }\end{array}$ & $\begin{array}{l}2 \text { or more items } \\
L\end{array}$ & $\mathrm{R}-\mathrm{L}$ & $\begin{array}{l}\text { A borigines } \\
\text { Temnes }\end{array}$ & $\begin{array}{l}10.5 \\
3.4\end{array}$ & $\begin{array}{l}10.7 \\
3.8\end{array}$ & $\begin{array}{l}5.9 \\
0.0\end{array}$ \\
\hline $\begin{array}{c}\text { A nnett, } 1973 \text { (A nnett, } \\
\text { M.., 1973b) }\end{array}$ & $\begin{array}{l}3644 \text { B ritish } \\
\text { students }\end{array}$ & $\begin{array}{l}\text { Self-selected } \\
\text { volunteers; } \\
\text { questionnaires } \\
\text { distributed in } \\
\text { class and by post }\end{array}$ & 2 & - & $\begin{array}{l}\text { 'A re you } \\
\text { R/L } \\
\text { handed?' }\end{array}$ & $\begin{array}{l}\text { A nswer to } \\
\text { question }\end{array}$ & $R-L$ & - & 11.6 & 11.8 & 11.5 \\
\hline
\end{tabular}

\begin{tabular}{|c|c|c|c|c|c|c|c|c|c|c|c|}
\hline $\begin{array}{c}\text { Newcombe and } \\
\text { Ratcliff, } 1973 \\
\text { (N ewcombe, F.\& } \\
\text { Ratcliff, G., 1973a) }\end{array}$ & $\begin{array}{l}823 \text { B ritish } \\
\text { adults }\end{array}$ & $\begin{array}{l}\text { Random sample } \\
\text { (control subjects) }\end{array}$ & 3 & - & $\begin{array}{l}\text { Written } \\
\text { questionnair } \\
\text { e }\end{array}$ & A ny item $L$ & $R-M-L$ & $\begin{array}{c}\mathrm{L} \\
\mathrm{L}+\mathrm{M}\end{array}$ & $\begin{array}{c}3.2 \\
20.0\end{array}$ & $\begin{array}{c}3.7 \\
26.2\end{array}$ & $\begin{array}{l}2.6 \\
13.8\end{array}$ \\
\hline $\begin{array}{l}\text { R hoads and Damon, } \\
1973 \text { (Rhoads, J.G. \& } \\
\text { Damon, A.., 1973) }\end{array}$ & $\begin{array}{l}1352 \text { Solomon } \\
\text { Island adults }\end{array}$ & $\begin{array}{l}\text { Random sample; } \\
\text { cross-cultural } \\
\text { study }\end{array}$ & 4 & - & $\begin{array}{l}\text { 'A re you } \\
\text { R/L } \\
\text { handed?' }\end{array}$ & $\begin{array}{l}\text { A nswer to } \\
\text { question }\end{array}$ & $R-L$ & - & 2.8 & - & - \\
\hline $\begin{array}{c}\text { B riggs and Nebes, } \\
1975 \text { (B riggs, G. G.\& } \\
\text { Nebes, R. D., 1975b) }\end{array}$ & $\begin{array}{l}1599 \text { A merican } \\
\text { students }\end{array}$ & $\begin{array}{l}\text { Captive whole } \\
\text { group; all } \\
\text { psychology } \\
\text { students over two } \\
\text { years at a } \\
\text { university }\end{array}$ & 3 & - & $\begin{array}{l}\text { Written } \\
\text { Questionnair } \\
\text { e }\end{array}$ & Laterality score & $R-M-L$ & $\begin{array}{c}L \\
L+M\end{array}$ & $\begin{array}{c}9.1 \\
14.4\end{array}$ & $\begin{array}{c}8.9 \\
14.6\end{array}$ & $\begin{array}{c}9.4 \\
14.2\end{array}$ \\
\hline $\begin{array}{c}\text { Newcombe et al.1975 } \\
\text { (N ewcombe, F. G. et } \\
\text { al., 1975) }\end{array}$ & $\begin{array}{l}928 \text { B ritish } \\
\text { adults }\end{array}$ & $\begin{array}{l}\text { Self-selected } \\
\text { volunteers from a } \\
\text { group of }\end{array}$ & 2 & $90 \%$ & $\begin{array}{l}\text { W ritten } \\
\text { questionnair } \\
\text { e }\end{array}$ & A ny item $L$ & $R-L$ & - & 6.4 & 8.0 & 4.7 \\
\hline
\end{tabular}

(Table continued) 


\begin{tabular}{|c|c|c|c|c|c|c|c|c|c|c|c|}
\hline & & $\begin{array}{l}\text { Oxfordshire } \\
\text { villages }\end{array}$ & & & & & & & & & \\
\hline $\begin{array}{c}\text { A nnett, } 1976 \text { (A nnett, } \\
\text { M., 1976) }\end{array}$ & $\begin{array}{l}804 \text { B ritish } \\
\text { students }\end{array}$ & $\begin{array}{l}\text { Captive whole } \\
\text { group; class at } \\
\text { Open University } \\
\text { summer school } \\
\end{array}$ & 2 & - & $\begin{array}{l}\text { Verbal } \\
\text { questionnair } \\
\mathrm{e}\end{array}$ & - & $\mathrm{R}-\mathrm{L}$ & - & 7.6 & - & - \\
\hline $\begin{array}{c}\text { Hardyck, Petrinovich } \\
\text { and Goldman, } 1976 \\
\text { (Hardyck, C.', } \\
\text { Petrinovich, L. F., \& } \\
\text { Goldman, R. D., 1976b) }\end{array}$ & $\begin{array}{l}7688 \text { A merican } \\
\text { children }\end{array}$ & $\begin{array}{l}\text { Captive whole } \\
\text { group; total } \\
\text { population of } \\
\text { school children } \\
\text { in a medium- } \\
\text { sized community }\end{array}$ & 2 & - & $\begin{array}{l}\text { Performance } \\
\text { of } 3 \text { tasks } \\
\text { (writing, } \\
\text { cutting, } \\
\text { holding tube } \\
\text { to eye) }\end{array}$ & A ny item $L$ & $R-L$ & - & 9.6 & 10.5 & 8.7 \\
\hline $\begin{array}{c}\text { Hatta and Nakatsuka, } \\
1976(\mathrm{Hatta}, \mathrm{T} . \& \\
\text { Nakatsuka, Z., 1976d) }\end{array}$ & $\begin{array}{l}1199 \text { J apanese } \\
\text { adults }\end{array}$ & $\begin{array}{l}\text { R andom sample; } \\
\text { subjects obtained } \\
\text { from offices and } \\
\text { colleges }\end{array}$ & 3 & - & $\begin{array}{l}\text { Written } \\
\text { questionnair } \\
\text { e }\end{array}$ & L aterality score & $R-L$ & - & 3.1 & 4.3 & 2.3 \\
\hline $\begin{array}{c}\text { Heim and W atts, } 1976 \\
\text { (Heim, A. W. \& W atts, } \\
\text { K.P., 1976c) }\end{array}$ & $\begin{array}{l}2165 \text { B ritish } \\
\text { children and } \\
\text { students }\end{array}$ & $\begin{array}{l}\text { Random sample } \\
\text { in schools and } \\
\text { colleges }\end{array}$ & 3 & - & $\begin{array}{l}\text { Writing } \\
\text { hand }\end{array}$ & W riting hand & $\mathrm{R}-\mathrm{L}$ & - & 9.4 & 11.3 & 7.5 \\
\hline $\begin{array}{l}\text { Fleminger, Dalton and } \\
\text { Standage, 1977 } \\
\text { (Fleminger, J. J., } \\
\text { Dalton, E., \& Standage, } \\
\text { K. F., 1977) }\end{array}$ & $\begin{array}{l}800 \text { B ritish } \\
\text { adults }\end{array}$ & $\begin{array}{l}\text { Random sample; } \\
\text { control group } \\
\text { drawn from } \\
\text { Dental } \\
\text { Department at } \\
\text { Guy's Hospital } \\
\end{array}$ & 4 & - & $\begin{array}{l}\text { Written } \\
\text { questionnair } \\
\mathrm{e}\end{array}$ & W riting hand & $R-L$ & - & 8.8 & - & - \\
\hline $\begin{array}{c}\text { Gur and Gur, } 1977 \\
\text { (Gur, R. E. \& Gur, R. } \\
\text { C., 1977) }\end{array}$ & $\begin{array}{l}200 \text { A merican } \\
\text { adults }\end{array}$ & $\begin{array}{l}\text { Random sample; } \\
\text { control group } \\
\text { drawn from } \\
\text { workers and non- } \\
\text { psychiatric } \\
\text { patients }\end{array}$ & 4 & - & $\begin{array}{l}\text { Written } \\
\text { questionnair } \\
\mathrm{e}\end{array}$ & L aterality score & $\mathrm{R}-\mathrm{L}$ & - & 11.0 & 16.0 & 6.0 \\
\hline $\begin{array}{c}\text { Schwartz, } 1977 \\
\text { (Schwartz, M., 1977) }\end{array}$ & $\begin{array}{l}584 \text { Canadian } \\
\text { students }\end{array}$ & $\begin{array}{l}\text { Self-selected } \\
\text { volunteers } \\
\text { obtained in } \\
\text { university classes }\end{array}$ & 2 & - & $\begin{array}{l}\text { Written } \\
\text { questionnair } \\
\mathrm{e}\end{array}$ & Laterality score & $R-L$ & - & 10.1 & - & - \\
\hline $\begin{array}{c}\text { Hicks, Pellegrini and } \\
\text { Evans, } 1978 \text { (Hicks, R. } \\
\text { A., Pellegrini, R. J., \& } \\
\text { Evans, E. A., 1978) }\end{array}$ & $\begin{array}{l}728 \text { A merican } \\
\text { students }\end{array}$ & $\begin{array}{l}\text { Captive whole } \\
\text { group; } \\
\text { University } \\
\text { freshmen }\end{array}$ & 3 & - & $\begin{array}{l}\text { Written } \\
\text { questionnair } \\
\text { e }\end{array}$ & L aterality score & $R-L$ & - & 8.5 & 11.2 & 5.8 \\
\hline $\begin{array}{l}\text { Kobyliansky, Micle } \\
\text { and A rensburg, } 1978 \\
\text { (K obyliansky, E., }\end{array}$ & $\begin{array}{l}1081 \text { Israeli } \\
\text { males }\end{array}$ & R andom sample & 4 & - & $\begin{array}{l}\text { 'A re you } \\
\text { R/L }\end{array}$ & $\begin{array}{l}\text { A nswer to } \\
\text { question }\end{array}$ & $R-M-L$ & $\begin{array}{c}\text { Middle East } R \\
\text { M iddle East } \\
R+M\end{array}$ & $\begin{array}{l}4.2 \\
6.8 \\
9.8\end{array}$ & $\begin{array}{l}4.2 \\
6.8 \\
9.8\end{array}$ & $\begin{array}{l}- \\
- \\
-\end{array}$ \\
\hline
\end{tabular}

(Table continued) 


\begin{tabular}{|c|c|c|c|c|c|c|c|c|c|c|c|}
\hline $\begin{array}{c}\text { M icle, S., \& A rensburg, } \\
\text { B., 1978) }\end{array}$ & & & & & handed?' & & & $\begin{array}{c}\text { North A frica R } \\
\text { North A frica } \\
R+M \\
\text { Europe } R \\
\text { Europe } R+M \\
\end{array}$ & $\begin{array}{l}10.4 \\
13.3 \\
16.2\end{array}$ & $\begin{array}{l}10.4 \\
13.3 \\
16.2\end{array}$ & $\begin{array}{l}- \\
- \\
-\end{array}$ \\
\hline $\begin{array}{c}\text { Peters, } 1986 \text { (Peters, } \\
\text { M ., 1986) }\end{array}$ & $\begin{array}{l}5910 \text { Canadian } \\
\text { children }\end{array}$ & $\begin{array}{l}\text { Captive whole } \\
\text { group of schools } \\
\text { in } 3 \text { different } \\
\text { districts }\end{array}$ & 2 & $100 \%$ & $\begin{array}{l}\text { W riting } \\
\text { hand }\end{array}$ & W riting hand & $R-L$ & - & 11.0 & 11.9 & 10.0 \\
\hline $\begin{array}{c}\text { Searleman, Tweedy } \\
\text { and Springer, } 1979 \\
\text { (Searleman, A., } \\
\text { Tweedy, J., \& Springer, } \\
\text { S., 1979b) }\end{array}$ & $\begin{array}{l}847 \text { A merican } \\
\text { students }\end{array}$ & $\begin{array}{l}\text { Captive whole } \\
\text { group of } \\
\text { university } \\
\text { students }\end{array}$ & 3 & - & $\begin{array}{l}\text { 'A re you } \\
\mathrm{R} / \mathrm{L} \\
\text { handed?' }\end{array}$ & $\begin{array}{l}\text { A nswer to } \\
\text { question }\end{array}$ & $R-M-L$ & $\stackrel{L}{L+M}$ & $\begin{array}{l}13.5 \\
16.5\end{array}$ & $\begin{array}{l}13.8 \\
17.2\end{array}$ & $\begin{array}{l}13.3 \\
16.1\end{array}$ \\
\hline $\begin{array}{c}\text { Silverberg, Obler and } \\
\text { Gordon, } 1979 \\
\text { (Silverberg, R., Obler, } \\
\text { L. K.., \& Gordon, H. } \\
\text { W., 1979) }\end{array}$ & $\begin{array}{l}1171 \text { Israeli } \\
\text { children }\end{array}$ & $\begin{array}{l}\text { Captive whole } \\
\text { group; all } \\
\text { children in last } 3 \\
\text { grades of } 4 \\
\text { randomly } \\
\text { selected schools }\end{array}$ & 2 & - & $\begin{array}{l}\text { Written } \\
\text { questionnair } \\
\text { e }\end{array}$ & $\mathrm{LQ}<0$ & $R-L$ & - & 10.2 & 8.6 & 11.8 \\
\hline $\begin{array}{c}\text { Teng et al. } 1979 \text { (Teng, } \\
\text { E. L., L ee, P-H., Y ang, } \\
\text { K-S., \& Chang, P. C., } \\
\text { 1979a) }\end{array}$ & $\begin{array}{l}4143 \text { Chinese } \\
\text { students and } \\
\text { children }\end{array}$ & $\begin{array}{l}\text { Captive whole } \\
\text { group; school } \\
\text { and university } \\
\text { classes }\end{array}$ & 2 & - & $\begin{array}{l}\text { Written } \\
\text { questionnair } \\
\text { e }\end{array}$ & $\mathrm{LQ}<0$ & $R-L$ & - & 4.5 & 6.0 & 3.0 \\
\hline $\begin{array}{c}\text { Coren and Porac, } 1980 \\
\text { (Coren, S. \& Porac, C., } \\
\text { 1980) }\end{array}$ & $\begin{array}{l}2761 \text { Canadian } \\
\text { adults }\end{array}$ & $\begin{array}{l}\text { Self-selected } \\
\text { volunteers } \\
\text { contacted by } \\
\text { postal } \\
\text { questionnaire } \\
\end{array}$ & 4 & $28 \%$ & $\begin{array}{l}\text { Written } \\
\text { questionnair } \\
\text { e }\end{array}$ & $\mathrm{LQ}<0$ & $R-L$ & - & 10.9 & 11.4 & 10.4 \\
\hline $\begin{array}{c}\text { Dusek and Hicks, } 1980 \\
\text { (Dusek, C. D. \& Hicks, } \\
\text { R. A., 1980) }\end{array}$ & $\begin{array}{l}600 \text { A merican } \\
\text { children }\end{array}$ & R andom sample & 4 & - & $\begin{array}{l}\text { Written } \\
\text { questionnair } \\
\text { e }\end{array}$ & L aterality score & $R-L$ & - & 9.2 & 9.1 & 9.2 \\
\hline $\begin{array}{l}\text { Hicks and Dusek, } 1980 \\
\text { (Hicks, R. A. \& Dusek, } \\
\text { C. M., 1980) }\end{array}$ & $\begin{array}{l}578 \text { A merican } \\
\text { children }\end{array}$ & Random sample & 3 & - & $\begin{array}{l}\text { W ritten } \\
\text { questionnair } \\
\text { e }\end{array}$ & L aterality score & $R-M-L$ & $\stackrel{L}{L+M}$ & $\begin{array}{c}8.4 \\
16.8\end{array}$ & $\begin{array}{l}- \\
-\end{array}$ & $\begin{array}{l}- \\
-\end{array}$ \\
\hline
\end{tabular}




\begin{tabular}{|c|c|c|c|c|c|c|c|c|c|c|c|}
\hline $\begin{array}{c}\text { Hicks et al. } 1980 \\
\text { (Hicks, R. A., Dusek, } \\
\text { C., Larsen, F., Williams, } \\
\text { S., \& Pellegrini, R. J., } \\
\text { 1980) }\end{array}$ & $\begin{array}{l}1501 \text { A merican } \\
\text { students }\end{array}$ & $\begin{array}{l}\text { Captive whole } \\
\text { group; freshmen } \\
\text { at university }\end{array}$ & 2 & - & $\begin{array}{l}\text { Written } \\
\text { questionnair } \\
\text { e }\end{array}$ & L aterality score & $R-M-L$ & $L L+M$ & 6.812 .6 & -- & -- \\
\hline $\begin{array}{c}\text { Jones and Bell, } 1980 \\
\text { (J ones, B. \& B ell, J., } \\
\text { 1980a) }\end{array}$ & $\begin{array}{l}299 \text { Canadian } \\
\text { students }\end{array}$ & $\begin{array}{l}\text { Captive whole } \\
\text { group; all first } \\
\text { year psychology } \\
\text { and engineering } \\
\text { students at a } \\
\text { university }\end{array}$ & 3 & - & $\begin{array}{l}\text { Written } \\
\text { questionnair } \\
\text { e }\end{array}$ & $L Q<0$ & $R-L$ & - & 12.2 & 12.7 & 12.7 \\
\hline $\begin{array}{c}\text { M cFarland and } \\
\text { A nderson, } 1980 \\
\text { (M cF arland, K. \& } \\
\text { A nderson, J., 1980) }\end{array}$ & $\begin{array}{l}600 \text { B ritish } \\
\text { students }\end{array}$ & $\begin{array}{l}\text { Random sample } \\
\text { from } 2 \text { schools } \\
\text { and } 2 \text { universities }\end{array}$ & 3 & - & $\begin{array}{l}\text { Written } \\
\text { questionnair } \\
\text { e }\end{array}$ & W riting hand & $R-L$ & - & 9.3 & 10.4 & 8.1 \\
\hline $\begin{array}{c}\text { Tan and N ettleton, } \\
1980 \text { (Tan, L. E. \& } \\
\text { N ettleton, N. C., 1980) } \\
\end{array}$ & $\begin{array}{l}942 \text { A ustralian } \\
\text { students and } \\
\text { children }\end{array}$ & Random sample & 2 & - & $\begin{array}{l}\text { Written } \\
\text { questionnair } \\
\text { e }\end{array}$ & L aterality score & $R-L$ & - & 11.7 & 13.6 & 10.7 \\
\hline $\begin{array}{c}\text { B irkett, } 1981 \text { (B irkett, } \\
\text { P., 1981C) }\end{array}$ & $\begin{array}{l}125 \text { B ritish } \\
\text { subjects }\end{array}$ & $\begin{array}{l}\text { Self-selected } \\
\text { volunteers from } \\
\text { schools, colleges } \\
\text { and the public }\end{array}$ & 4 & - & $\begin{array}{l}\text { Written } \\
\text { questionnair } \\
\text { e }\end{array}$ & $L Q<0$ & $R-L$ & - & 41.6 & 38.9 & 43.7 \\
\hline $\begin{array}{c}\text { Hebben, B enjamins } \\
\text { and M ilberg, 1981 } \\
\text { (Hebben, N., } \\
\text { Benjamins, D., \& } \\
\text { M ilberg, W. P., 1981) }\end{array}$ & $\begin{array}{l}191 \text { A merican } \\
\text { children }\end{array}$ & Random sample & 2 & - & $\begin{array}{l}\text { Verbal } \\
\text { questionnair } \\
\text { e }\end{array}$ & L aterality score & $R-L$ & - & 9.0 & 9.6 & 8.2 \\
\hline $\begin{array}{l}\text { Leiber and A xel rod, } \\
1981 \text { (L eiber, L. \& } \\
\text { A xelrod, S., 1981a) }\end{array}$ & $\begin{array}{l}15767 \text { A merican } \\
\text { students and } \\
\text { relatives }\end{array}$ & $\begin{array}{l}\text { Self-selected } \\
\text { volunteers who } \\
\text { also reported on } \\
\text { first degree } \\
\text { relatives }\end{array}$ & 3 & - & $\begin{array}{l}\text { 'A re you } \\
\text { R/L } \\
\text { handed?' }\end{array}$ & $\begin{array}{l}\text { A nswer to } \\
\text { question }\end{array}$ & $R-M-L$ & $\stackrel{L}{L+M}$ & $\begin{array}{c}8.6 \\
11.0\end{array}$ & $\begin{array}{c}9.8 \\
12.9\end{array}$ & $\begin{array}{l}7.3 \\
9.0\end{array}$ \\
\hline $\begin{array}{c}\text { M ascie-Taylor, } 1981 \\
\text { (M ascie-Taylor, C. G. } \\
\text { N., 1981) }\end{array}$ & $\begin{array}{l}386 \text { B ritish } \\
\text { adults }\end{array}$ & $\begin{array}{l}\text { Captive whole } \\
\text { group of } 193 \\
\text { couples from a } \\
\text { single housing } \\
\text { estate }\end{array}$ & 1 & $100 \%$ & $\begin{array}{l}\text { Writing } \\
\text { hand }\end{array}$ & W riting hand & $R-L$ & - & 8.0 & 8.8 & 7.3 \\
\hline $\begin{array}{l}\text { M cM anus, 1981, } \\
\text { unpublished }\end{array}$ & $\begin{array}{l}340 \text { B ritish } \\
\text { students }\end{array}$ & $\begin{array}{l}\text { Captive whole } \\
\text { group of } \\
\text { applicants to }\end{array}$ & 2 & $92 \%$ & $\begin{array}{l}\text { 'A re you } \\
\mathrm{R} / \mathrm{L} \\
\text { handed?' }\end{array}$ & $\begin{array}{l}\text { A nswer to } \\
\text { question }\end{array}$ & $R-L$ & - & 10.3 & 10.0 & 10.7 \\
\hline
\end{tabular}

(Table continued) 


\begin{tabular}{|c|c|c|c|c|c|c|c|c|c|c|}
\hline & & medical school & & & & & & & & \\
\hline $\begin{array}{c}\text { Porac and Coren, } 1981 \\
\text { (Porac, C. \& Coren, S., } \\
\text { 1981d) }\end{array}$ & $\begin{array}{l}5147 \text { Canadian } \\
\text { adults }\end{array}$ & $\begin{array}{l}\text { Self-selected } \\
\text { volunteers, sent } \\
\text { questionnaires by } \\
\text { post }\end{array}$ & 4 & $26 \%$ & $\begin{array}{l}\text { Written } \\
\text { questionnair } \\
\text { e }\end{array}$ & $L Q<0$ & $R-L$ & 11.8 & 13.5 & 9.9 \\
\hline
\end{tabular}

\begin{tabular}{|c|c|c|c|c|c|c|c|c|c|c|c|}
\hline $\begin{array}{l}\text { A shton, } 1982 \text { (A shton, } \\
\text { G. C.., 1982b) }\end{array}$ & $\begin{array}{l}2027 \text { Hawaiian } \\
\text { children and } \\
\text { parents }\end{array}$ & $\begin{array}{l}\text { Random sample } \\
\text { of families for } \\
\text { the Hawaii } \\
\text { Family Study of } \\
\text { Cognition }\end{array}$ & 3 & - & $\begin{array}{l}\text { Writing } \\
\text { hand }\end{array}$ & W riting hand & $\mathrm{R}-\mathrm{L}$ & $\begin{array}{l}\text { Parents } \\
\text { Children }\end{array}$ & $\begin{array}{c}7.1 \\
10.5\end{array}$ & $\begin{array}{c}7.1 \\
11.9\end{array}$ & $\begin{array}{l}7.1 \\
9.1\end{array}$ \\
\hline $\begin{array}{l}\text { Bonvillian, Orlansky } \\
\text { and Garland, } 1982 \\
\text { (Bonvillian, J. D., } \\
\text { Orlansky, M. D.., \& } \\
\text { Garland, J. B., 1982) } \\
\end{array}$ & $\begin{array}{l}210 \text { A merican } \\
\text { students }\end{array}$ & $\begin{array}{l}\text { Self-selected } \\
\text { volunteers; } \\
\text { university } \\
\text { students acting as } \\
\text { controls }\end{array}$ & 3 & - & $\begin{array}{l}\text { Written } \\
\text { questionnair } \\
\mathrm{e}\end{array}$ & Laterality score & $R-L$ & - & 7.1 & - & - \\
\hline $\begin{array}{c}\text { Provins, M ilner and } \\
\text { Kerr, } 1982 \text { (Provins, K. } \\
\text { A., M ilner, A.D., \& } \\
\text { Kerr, P., 1982C) }\end{array}$ & $\begin{array}{l}1966 \text { B ritish and } \\
\text { A ustralian } \\
\text { students }\end{array}$ & $\begin{array}{l}\text { Self-selected } \\
\text { volunteers: } \\
\text { students at six } \\
\text { universities }\end{array}$ & 2 & $100 \%$ & $\begin{array}{l}\text { Written } \\
\text { questionnair } \\
\mathrm{e}\end{array}$ & $\mathrm{LQ}<0$ & $R-L$ & - & 9.5 & 11.4 & 7.8 \\
\hline $\begin{array}{c}\text { N achson, Denno and } \\
\text { A urand, } 1983 \\
\text { (Nachson, I., Denno, } \\
\text { D., \& A urand, S., 1983) }\end{array}$ & $\begin{array}{l}7364 \text { A merican } \\
\text { children }\end{array}$ & $\begin{array}{l}\text { Randomly } \\
\text { selected for the } \\
\text { Philadel phia } \\
\text { Collaborative } \\
\text { Perinatal Project } \\
\text { (1959-1966) }\end{array}$ & 1 & - & $\begin{array}{l}\text { Writing } \\
\text { hand }\end{array}$ & W riting hand & $R-L$ & - & 11.9 & 13.3 & 10.4 \\
\hline $\begin{array}{c}\text { Porac, Coren and } \\
\text { Searleman, } 1983 \\
\text { (Porac, C., Coren, S., \& } \\
\text { Searleman, A., 1983b) }\end{array}$ & $\begin{array}{l}1341 \text { Canadian } \\
\text { parents and } \\
\text { children }\end{array}$ & $\begin{array}{l}\text { Self-selected } \\
\text { volunteers, sent } \\
\text { questionnaires by } \\
\text { post }\end{array}$ & 4 & $23 \%$ & $\begin{array}{l}\text { Written } \\
\text { questionnair } \\
\text { e }\end{array}$ & L aterality score & $R-L$ & $\begin{array}{l}\text { Parents } \\
\text { Children }\end{array}$ & $\begin{array}{c}7.1 \\
16.6\end{array}$ & $\begin{array}{c}7.6 \\
14.6\end{array}$ & $\begin{array}{c}6.7 \\
18.4\end{array}$ \\
\hline $\begin{array}{l}\text { Salmaso and Longoni, } \\
1983 \text { (Salmaso, D. \& } \\
\text { Longoni, A. M., 1983a) }\end{array}$ & $\begin{array}{l}1694 \text { Italian } \\
\text { students }\end{array}$ & $\begin{array}{l}\text { Self-selected } \\
\text { volunteers from } \\
\text { secondary } \\
\text { schools and } \\
\text { universities }\end{array}$ & 3 & - & $\begin{array}{l}\text { Written } \\
\text { questionnair } \\
\mathrm{e}\end{array}$ & $\mathrm{LQ}<0$ & $\mathrm{R}-\mathrm{L}$ & - & 6.4 & - & - \\
\hline
\end{tabular}




\begin{tabular}{|c|c|c|c|c|c|c|c|c|c|c|c|}
\hline $\begin{array}{c}\text { Shimizu and Endo, } \\
1983 \text { (Shimizu, A.\& } \\
\text { Endo, M., 1983) }\end{array}$ & $\begin{array}{l}4282 \text { J apanese } \\
\text { students }\end{array}$ & $\begin{array}{l}\text { Random sample } \\
\text { of five senior } \\
\text { schools }\end{array}$ & 2 & $96 \%$ & $\begin{array}{l}\text { Written } \\
\text { questionnair } \\
\text { e }\end{array}$ & L aterality score & $\mathrm{R}-\mathrm{NR}$ & - & 11.0 & 12.0 & 10.0 \\
\hline $\begin{array}{c}\text { Spiegler and } \\
\text { Y eni-K omshian, } 1983 \\
\text { (Spiegler, B. J. \& Y eni- } \\
\text { K omshian, G. H., 1983) }\end{array}$ & $\begin{array}{l}1816 \text { A merican } \\
\text { students }\end{array}$ & Random sample & 2 & - & $\begin{array}{l}\text { Writing } \\
\text { hand }\end{array}$ & W riting hand & $R-L$ & - & 13.8 & 15.2 & 12.6 \\
\hline $\begin{array}{l}\text { Buchtel and Rueckert, } \\
1984 \text { (Buchtel, H. A. \& } \\
\text { Rueckert, L., 1984) }\end{array}$ & $\begin{array}{l}740 \text { A merican } \\
\text { students }\end{array}$ & $\begin{array}{l}\text { Captive whole } \\
\text { group of } \\
\text { psychology } \\
\text { students at a } \\
\text { university }\end{array}$ & 3 & - & $\begin{array}{l}\text { Written } \\
\text { questionnair } \\
\text { e }\end{array}$ & - & $R-L$ & - & 13.4 & 13.7 & 13.1 \\
\hline $\begin{array}{c}\text { Gillberg, Waldenström } \\
\text { and Rasmussen, } 1984 \\
\text { (Gillberg, C., } \\
\text { Wal denström, E., \& } \\
\text { Rasmussen, P., 1984) }\end{array}$ & $\begin{array}{l}985 \text { Swedish } \\
\text { children }\end{array}$ & $\begin{array}{l}\text { Random sample } \\
\text { of school } \\
\text { children in a } \\
\text { single town }\end{array}$ & 2 & - & $\begin{array}{l}\text { Writing } \\
\text { hand }\end{array}$ & W riting hand & $R-L$ & - & 9.2 & 10.9 & 7.4 \\
\hline
\end{tabular}

\begin{tabular}{|c|c|c|c|c|c|c|c|c|c|c|c|}
\hline $\begin{array}{c}\text { Plato, Fox and Garruto, } \\
1984 \text { (Plato, C. C.., Fox, } \\
\text { K. M.., \& Garruto, R. } \\
\text { M., 1984) }\end{array}$ & $\begin{array}{l}705 \text { A merican } \\
\text { adults }\end{array}$ & $\begin{array}{l}\text { Randomly } \\
\text { selected for the } \\
\text { B altimore } \\
\text { Longitudinal } \\
\text { Study of A ging }\end{array}$ & 3 & - & $\begin{array}{l}\text { Performance } \\
\text { of unskilled } \\
\text { task }\end{array}$ & W riting hand & $R-L$ & - & 5.5 & 6.9 & 4.1 \\
\hline $\begin{array}{c}\text { Rymar et al. } 1984 \\
\text { (Rymar, K., } \\
\text { Kameyama, T., Niwa, } \\
\text { S-I., Hiramatsu, K-I., \& } \\
\text { Saitoh, O., 1984) }\end{array}$ & $\begin{array}{l}725 \text { J apanese } \\
\text { children }\end{array}$ & $\begin{array}{l}\text { Randomly } \\
\text { selected classes } \\
\text { form } 6 \text { schools in } \\
\text { Tokyo }\end{array}$ & 1 & $100 \%$ & $\begin{array}{l}\text { Performance } \\
\text { of } 7 \text { tasks } \\
\text { (e.g. writing, } \\
\text { throwing, } \\
\text { etc.) }\end{array}$ & Laterality score & $R-M-L$ & $\stackrel{L}{L+M}$ & $\begin{array}{l}3.7 \\
9.8\end{array}$ & $\begin{array}{l}- \\
-\end{array}$ & $\begin{array}{l}- \\
-\end{array}$ \\
\hline $\begin{array}{c}\text { Segal, } 1984 \text { (Segal, N. } \\
\text { L., 1984) }\end{array}$ & $\begin{array}{l}1577 \text { A merican } \\
\text { students }\end{array}$ & $\begin{array}{l}\text { Captive whole } \\
\text { group of all } \\
\text { students sitting } \\
\text { exams at a single } \\
\text { centre on one }\end{array}$ & 1 & $100 \%$ & $\begin{array}{l}\text { Writing } \\
\text { hand } \\
\text { observed }\end{array}$ & W riting hand & $R-L$ & - & 9.6 & 10.0 & 9.0 \\
\hline
\end{tabular}

(Table continued) 


\begin{tabular}{|c|c|c|c|c|c|c|c|c|c|c|c|}
\hline & & day & & & & & & & & & \\
\hline $\begin{array}{l}\text { M cM anus, } 1985 \\
\text { (M cM anus, I. C.., } \\
\text { 1985a) - ICM } 1\end{array}$ & $\begin{array}{l}613 \text { B ritish } \\
\text { students and } \\
\text { relatives }\end{array}$ & $\begin{array}{l}\text { Self-selected } \\
\text { volunteers at } \\
\text { university, who } \\
\text { also reported on } \\
\text { siblings and } \\
\text { parents }\end{array}$ & 3 & $50 \%$ & $\begin{array}{l}\text { Writing } \\
\text { hand }\end{array}$ & W riting hand & $R-L$ & $\begin{array}{l}\text { Parents } \\
\text { Children }\end{array}$ & $\begin{array}{l}6.7 \\
9.7\end{array}$ & - & $\begin{array}{l}- \\
-\end{array}$ \\
\hline $\begin{array}{l}\text { M CM anus, } 1985 \\
\text { (M CM anus, I. C.., } \\
\text { 1985a) - ICM } 2\end{array}$ & $\begin{array}{l}837 \text { B ritish } \\
\text { students and } \\
\text { relatives }\end{array}$ & $\begin{array}{l}\text { Self-selected } \\
\text { student } \\
\text { volunteers and } \\
\text { their parents, } \\
\text { who reported on } \\
\text { siblings, aunts, } \\
\text { uncles and } \\
\text { grandparents }\end{array}$ & 3 & $20 \%$ & $\begin{array}{l}\text { Writing } \\
\text { hand }\end{array}$ & W riting hand & $R-L$ & $\begin{array}{l}\text { Grandparents } \\
\text { Parents } \\
\text { Children }\end{array}$ & $\begin{array}{l}3.2 \\
4.5 \\
9.8\end{array}$ & $\begin{array}{l}- \\
- \\
-\end{array}$ & $\begin{array}{l}- \\
- \\
-\end{array}$ \\
\hline $\begin{array}{c}\text { Tapley and Bryden, } \\
1985 \text { (Tapley, S. M. \& } \\
\text { Bryden, M. P., 1985) }\end{array}$ & $\begin{array}{l}1523 \text { Canadian } \\
\text { students }\end{array}$ & $\begin{array}{l}\text { Self-selected } \\
\text { volunteers: } \\
\text { psychology } \\
\text { students at a } \\
\text { university } \\
\end{array}$ & 2 & - & $\begin{array}{l}\text { W ritten } \\
\text { questionnair } \\
\text { e }\end{array}$ & Laterality score & $R-L$ & - & 11.7 & 13.0 & 10.8 \\
\hline $\begin{array}{c}\text { B eukelaar and } \\
\text { K roonenberg, } 1986 \\
\text { (B eukelaar, L. J . \& } \\
\text { K roonenberg, P. M., } \\
\text { 1986) } \\
\end{array}$ & $\begin{array}{l}1996 \text { Dutch } \\
\text { adults }\end{array}$ & $\begin{array}{l}\text { Self-selected } \\
\text { volunteers, sent } \\
\text { questionnaire by } \\
\text { post }\end{array}$ & 3 & $67 \%$ & $\begin{array}{l}\text { 'A re you } \\
\text { R/L } \\
\text { handed?' }\end{array}$ & $\begin{array}{l}\text { A nswer to } \\
\text { question }\end{array}$ & $R-L$ & - & 16.6 & - & - \\
\hline $\begin{array}{l}\text { M cM anus, 1986, } \\
\text { unpublished. }\end{array}$ & $\begin{array}{l}2028 \text { B ritish } \\
\text { students }\end{array}$ & $\begin{array}{l}\text { Captive whole } \\
\text { group: all } \\
\text { students applying } \\
\text { to medical } \\
\text { school }\end{array}$ & 2 & $94 \%$ & $\begin{array}{l}\text { 'A re you } \\
\text { R/L } \\
\text { handed?' }\end{array}$ & $\begin{array}{l}\text { A nswer to } \\
\text { question }\end{array}$ & $R-L$ & - & 11.0 & 11.1 & 11.0 \\
\hline $\begin{array}{c}\text { Peters, } 1986 \text { (Peters, } \\
\text { M., 1986) }\end{array}$ & $\begin{array}{l}2194 \text { German } \\
\text { children }\end{array}$ & $\begin{array}{l}\text { Random sample } \\
\text { of school } \\
\text { children }\end{array}$ & 2 & - & $\begin{array}{l}\text { W ritten } \\
\text { questionnair } \\
\text { e }\end{array}$ & - & $R-L$ & - & 9.0 & 10.6 & 7.4 \\
\hline $\begin{array}{c}\text { Porac, Coren and } \\
\text { Searleman, } 1986 \\
\text { (Porac, C., Coren, S., \& } \\
\text { Searleman, A., 1986c) }\end{array}$ & $\begin{array}{l}650 \text { Canadian } \\
\text { students }\end{array}$ & $\begin{array}{l}\text { Captive whole } \\
\text { group }\end{array}$ & 2 & - & $\begin{array}{l}\text { Written } \\
\text { questionnair } \\
\text { e }\end{array}$ & L aterality score & $R-L$ & - & 11.6 & - & - \\
\hline $\begin{array}{c}\text { Strauss, } 1986 \text { (Strauss, } \\
\text { E., 1986) }\end{array}$ & $\begin{array}{l}197 \text { Canadian } \\
\text { students }\end{array}$ & $\begin{array}{l}\text { Self-selected } \\
\text { volunteers }\end{array}$ & 3 & - & $\begin{array}{l}\text { W ritten } \\
\text { questionnair } \\
\text { e }\end{array}$ & Laterality score & $\mathrm{R}-\mathrm{NR}$ & - & 11.8 & - & - \\
\hline $\begin{array}{c}\text { Chapman and } \\
\text { Chapman, } 1987\end{array}$ & 2931 A merican & $\begin{array}{l}\text { Captive whole } \\
\text { group of }\end{array}$ & 3 & - & $\begin{array}{l}\text { Written } \\
\text { questionnair }\end{array}$ & L aterality score & $R-L$ & - & 9.0 & 9.4 & 8.6 \\
\hline
\end{tabular}

(Table continued) 


\begin{tabular}{|c|c|c|c|c|c|c|c|c|c|c|c|}
\hline $\begin{array}{c}\text { (Chapman, L. J. \& } \\
\text { Chapman, J. P., 1987) }\end{array}$ & students & $\begin{array}{l}\text { psychology } \\
\text { students at a } \\
\text { university }\end{array}$ & & & $\mathrm{e}$ & & & & & & \\
\hline $\begin{array}{l}\text { Chapman, Chapman } \\
\text { and A llen, } 1987 \\
\text { (Chapman, J. P.., } \\
\text { Chapman, L. J., \& } \\
\text { Allen, J.A., 1987) } \\
\end{array}$ & $\begin{array}{l}311 \text { A merican } \\
\text { students }\end{array}$ & $\begin{array}{l}\text { Randomly } \\
\text { selected } \\
\text { psychology } \\
\text { students at a } \\
\text { university } \\
\end{array}$ & 3 & - & $\begin{array}{l}\text { Written } \\
\text { questionnair } \\
\text { e }\end{array}$ & L aterality score & $R-L$ & - & 20.3 & - & - \\
\hline $\begin{array}{l}\text { Payne, } 1987 \text { (Payne, } \\
\text { M. A., 1987) }\end{array}$ & $\begin{array}{l}201 \text { Nigerian } \\
\text { students }\end{array}$ & $\begin{array}{l}\text { Self-selected } \\
\text { volunteers at a } \\
\text { university }\end{array}$ & 2 & - & $\begin{array}{l}\text { Written } \\
\text { questionnair } \\
\text { e }\end{array}$ & $\mathrm{LQ}<0$ & $R-L$ & - & 10.0 & - & - \\
\hline $\begin{array}{c}\text { Pipe, } 1987 \text { (Pipe, M., } \\
\text { 1987) }\end{array}$ & $\begin{array}{l}239 \mathrm{New} \\
\text { Zeal and children }\end{array}$ & $\begin{array}{l}\text { Randomly } \\
\text { selected control } \\
\text { group }\end{array}$ & 2 & - & $\begin{array}{l}\text { Performance } \\
\text { of unskilled } \\
\text { task }\end{array}$ & L aterality score & $R-N R$ & - & 18.0 & - & - \\
\hline $\begin{array}{c}\text { Schacter, Ransil and } \\
\text { Geschwind, } 1987 \\
\text { (Schacter, S. C., Ransil, } \\
\text { B. J., \& Geschwind, N., } \\
\text { 1987) } \\
\end{array}$ & $\begin{array}{l}1117 \text { A merican } \\
\text { adults }\end{array}$ & $\begin{array}{l}\text { Randomly } \\
\text { selected } \\
\text { professionals }\end{array}$ & 2 & $41 \%$ & $\begin{array}{l}\text { Written } \\
\text { questionnair } \\
\text { e }\end{array}$ & $L Q<0$ & $R-L$ & - & 12.4 & - & - \\
\hline $\begin{array}{c}\text { Searleman, Tweedy } \\
\text { and Springer, } 1979 \\
\text { (Searleman, A., } \\
\text { Tweedy, J., \& Springer, } \\
\text { S., 1979b) }\end{array}$ & $\begin{array}{l}277 \text { A merican } \\
\text { students }\end{array}$ & $\begin{array}{l}\text { Self-selected } \\
\text { students acting as } \\
\text { controls }\end{array}$ & 3 & - & $\begin{array}{l}\text { Written } \\
\text { questionnair } \\
\text { e }\end{array}$ & L aterality score & $R-L$ & - & 12.6 & 14.7 & 10.8 \\
\hline $\begin{array}{c}\text { Smith, } 1987 \text { (Smith, J., } \\
\text { 1987) }\end{array}$ & $\begin{array}{l}350 \text { B ritish } \\
\text { adults }\end{array}$ & $\begin{array}{l}\text { Self-selected } \\
\text { volunteers acting } \\
\text { as controls }\end{array}$ & 2 & - & $\begin{array}{l}\text { W ritten } \\
\text { questionnair } \\
\mathrm{e}\end{array}$ & L aterality score & $R-L$ & - & 8.9 & 11.0 & 7.0 \\
\hline $\begin{array}{c}\text { Cosi, Citterio and } \\
\text { Pasquino, } 1988 \text { (Cosi, } \\
\text { V., Citterio, A.., \& } \\
\text { Pasquino, C., 1988) }\end{array}$ & 178 Italian adults & $\begin{array}{l}\text { Self-selected } \\
\text { volunteers acting } \\
\text { as controls }\end{array}$ & 4 & - & $\begin{array}{l}\text { Written } \\
\text { questionnair } \\
\text { e }\end{array}$ & L aterality score & $R-L$ & - & 6.2 & 5.2 & 6.7 \\
\hline $\begin{array}{c}\text { Ellis, Ellis and } \\
\text { M arshall, } 1988 \text { (Ellis, S. } \\
\text { J., Ellis, P. J., \& } \\
\text { M arshall, E., 1988) }\end{array}$ & $\begin{array}{l}6097 \text { B ritish } \\
\text { adults }\end{array}$ & $\begin{array}{l}\text { Random sample } \\
\text { for a G eneral } \\
\text { M edical Practice }\end{array}$ & 2 & $82 \%$ & $\begin{array}{l}\text { Written } \\
\text { questionnair } \\
\text { e }\end{array}$ & $\mathrm{LQ}<0$ & $R-L$ & - & 7.9 & 8.4 & 9.6 \\
\hline $\begin{array}{l}\text { Lansky, Feinstein and } \\
\text { Peterson, } 1988 \text { (L ansky, } \\
\text { L. M ., Feinstein, H., \& } \\
\text { Peterson, J. M., 1988) }\end{array}$ & $\begin{array}{l}2083 \text { A merican } \\
\text { adults }\end{array}$ & $\begin{array}{l}\text { Randomly } \\
\text { selected subjects, } \\
\text { contacted by } \\
\text { telephone survey }\end{array}$ & 1 & - & $\begin{array}{l}\text { Verbal } \\
\text { questionnair } \\
\text { e }\end{array}$ & - & $R-L$ & - & 7.2 & 9.4 & 5.6 \\
\hline $\begin{array}{l}\text { Levander and } \\
\text { Schalling, } 1988\end{array}$ & $\begin{array}{l}921 \text { Swedish } \\
\text { students }\end{array}$ & $\begin{array}{l}\text { Captive whole } \\
\text { group of students }\end{array}$ & 1 & $100 \%$ & $\begin{array}{l}\text { Writing } \\
\text { hand }\end{array}$ & W riting hand & $R-L$ & - & 8.9 & 8.0 & 10.0 \\
\hline
\end{tabular}

(Table continued) 


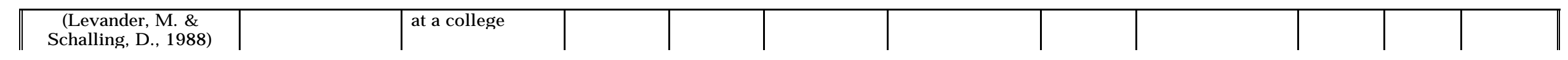

\begin{tabular}{|c|c|c|c|c|c|c|c|c|c|c|c|}
\hline $\begin{array}{l}\text { la et al. } 1989 \\
\text { A. et al., 1989) }\end{array}$ & $\begin{array}{l}266 \text { Colombian } \\
\text { students }\end{array}$ & $\begin{array}{l}\text { Random samples } \\
\text { of subjects from } \\
2 \text { different towns }\end{array}$ & 4 & - & $\begin{array}{l}\text { Written } \\
\text { questionnair } \\
\text { e }\end{array}$ & $L Q<0$ & $R-L$ & - & 8.7 & - & - \\
\hline $\begin{array}{l}\text { al. } 1989 \text { (B rito, } \\
\text { O., B rito, L. S. } \\
\text { imgartten, F.J. } \\
\text { Lins, M. F. C., } \\
\text { 1989a) }\end{array}$ & $\begin{array}{l}959 \text { Canadian } \\
\text { adults }\end{array}$ & $\begin{array}{l}\text { Self-selected } \\
\text { volunteers from } \\
\text { colleges, and an } \\
\text { engineering } \\
\text { company }\end{array}$ & 3 & - & $\begin{array}{l}\text { Verbal } \\
\text { questionnair } \\
\text { e }\end{array}$ & $L Q<0$ & $R-L$ & - & 6.9 & 8.5 & 5.3 \\
\hline $\begin{array}{l}\text { uis and Bryden, } \\
\text { iteenhuis, R. E. } \\
\text { en, M. P., 1989) }\end{array}$ & $\begin{array}{l}691 \text { Canadian } \\
\text { students }\end{array}$ & $\begin{array}{l}\text { Captive whole } \\
\text { group of first } \\
\text { year psychology } \\
\text { students }\end{array}$ & 2 & - & $\begin{array}{l}\text { Written } \\
\text { questionnair } \\
\text { e }\end{array}$ & $L Q<0$ & $R-L$ & - & 8.4 & 9.9 & 6.3 \\
\hline $\begin{array}{l}\text { uis and B ryden, } \\
\text { iteenhuis, R. E. } \\
\text { en, M. P., 1989) }\end{array}$ & $\begin{array}{l}251 \text { Canadian } \\
\text { students }\end{array}$ & $\begin{array}{l}\text { Self-selected } \\
\text { volunteers in a } \\
\text { single } \\
\text { psychology class }\end{array}$ & 2 & - & $\begin{array}{l}\text { Written } \\
\text { questionnair } \\
\text { e }\end{array}$ & $L Q<0$ & $R-L$ & - & 8.8 & - & - \\
\hline $\begin{array}{l}\text { I bach, de Ruiter } \\
\text { I Olff, } 1989 \\
\text { cel bach, H., de } \\
\text { C., \& Olff, M.., } \\
\text { 1989) }\end{array}$ & $\begin{array}{l}167 \text { Dutch } \\
\text { students }\end{array}$ & $\begin{array}{l}\text { Random sample } \\
\text { of first year } \\
\text { university } \\
\text { students }\end{array}$ & 3 & - & $\begin{array}{l}\text { Written } \\
\text { questionnair } \\
\text { e }\end{array}$ & $L Q<0$ & $R-M-L$ & $\begin{array}{c}\mathrm{L} \\
\mathrm{L}+\mathrm{M}\end{array}$ & $\begin{array}{l}10.2 \\
16.8\end{array}$ & $\begin{array}{l}- \\
-\end{array}$ & - \\
\hline $\begin{array}{l}1 \text { anus, 1990, } \\
\text { ipublished }\end{array}$ & $\begin{array}{l}16519 \text { B ritish } \\
\text { people }\end{array}$ & $\begin{array}{l}\text { Controls for the } \\
\text { National } \\
\text { Childhood } \\
\text { Encephalopathy } \\
\text { Study (NCES); } \\
\text { randomly } \\
\text { generated from } \\
\text { birth register. } \\
\text { Reported on by } \\
\text { parents who also } \\
\text { described } \\
\text { siblings, aunts, } \\
\text { uncles, and } \\
\text { grandparents. }\end{array}$ & 1 & $70 \%$ & $\begin{array}{l}\text { 'A re you } \\
\text { R/L } \\
\text { handed?' }\end{array}$ & $\begin{array}{l}\text { A nswer to } \\
\text { question }\end{array}$ & $R-L$ & $\begin{array}{l}\text { Grandparents } \\
\text { Parents } \\
\text { Children }\end{array}$ & $\begin{array}{c}5.4 \\
5.2 \\
10.9\end{array}$ & $\begin{array}{c}5.7 \\
5.7 \\
11.9\end{array}$ & $\begin{array}{l}5.0 \\
4.7 \\
9.9\end{array}$ \\
\hline
\end{tabular}


Table 2: the overall incidence of left-handedness in the studies.

The first part of the column marked classification shows the method used (e.g. R-L; right versus left-handed); (R-NR; right versus non-righthanded); and R-M -L (right versus mixed versus left-handedness), and the second part of the column shows the method of cal culating the proportion of left-handed subjects (e.g. $L /(L+R))$. The final row shows the combined data for the first three rows (but not including the fourth row).

\begin{tabular}{|c|c|c|c|c|c|c|c|c|c|c|}
\hline Classification & $\begin{array}{l}\text { Numbe } \\
\text { r of } \\
\text { studies }\end{array}$ & $\begin{array}{l}\text { Number } \\
\text { of } \\
\text { subjects }\end{array}$ & M edian & M ean & $\begin{array}{l}\text { Overall } \\
\text { incidence }\end{array}$ & Males & Females & $\begin{array}{c}\text { Overall } \\
\text { incidence: } \\
\text { Males }\end{array}$ & $\begin{array}{c}\text { Overall } \\
\text { incidence: } \\
\text { Females }\end{array}$ & $\begin{array}{c}100(M-F) \\
F\end{array}$ \\
\hline $\mathrm{R}-\mathrm{L}: \mathrm{L} /(\mathrm{L}+\mathrm{R})$ & 82 & 251698 & 9.0 & 9.17 & 7.68 & 122705 & 107056 & 8.44 & 6.59 & 28.1 \\
\hline $\mathrm{R}-\mathrm{NR}: \mathrm{NR} /(\mathrm{R}+\mathrm{NR})$ & 3 & 4718 & 11.8 & 13.60 & 11.38 & 2159 & 2123 & 12.00 & 10.00 & 20.0 \\
\hline $\mathrm{R}-\mathrm{M}-\mathrm{L}: \mathrm{L} /(\mathrm{R}+\mathrm{M}+\mathrm{L})$ & 15 & 28249 & 8.6 & 7.89 & 8.06 & 4399 & 2995 & 8.95 & 7.93 & 12.9 \\
\hline $\begin{array}{c}R-M-L: \\
(L+M) /(R+M+L) \\
\end{array}$ & 15 & 28249 & 16.2 & 17.65 & 15.16 & 4399 & 2995 & 16.69 & 11.99 & 39.2 \\
\hline $\begin{array}{cl}L /(R+L) \\
\text { Total }: & N R /(R+N R) \\
L /(R+M+L)\end{array}$ & 100 & 284665 & 9.0 & 9.11 & 7.78 & 129263 & 112174 & 8.52 & 6.69 & 27.4 \\
\hline
\end{tabular}


Table 3:

Incidence of left-handedness in relation to method of assessment of handedness.

\begin{tabular}{|c|c|c|c|c|c|c|c|c|c|c|}
\hline $\begin{array}{c}\text { M ethod of assessment } \\
\text { of handedness }\end{array}$ & $\begin{array}{c}\text { Numbe } \\
\text { r of } \\
\text { studies }\end{array}$ & $\begin{array}{c}\text { Number } \\
\text { of } \\
\text { subjects }\end{array}$ & M edian & M ean & $\begin{array}{c}\text { Overall } \\
\text { incidence }\end{array}$ & M ales & Females & $\begin{array}{c}\text { Overall } \\
\text { incidence: } \\
\text { M al es }\end{array}$ & $\begin{array}{c}\text { Overall } \\
\text { incidence: } \\
\text { Females }\end{array}$ & $\begin{array}{c}100(M-F) \\
------ \\
F\end{array}$ \\
\hline $\begin{array}{c}\text { Preference by written } \\
\text { questionnaire }\end{array}$ & 52 & 95385 & 9.2 & 9.93 & 8.89 & 35888 & 36.83 & 9.84 & 8.18 & 20.3 \\
\hline $\begin{array}{c}\text { Preference by verbal } \\
\text { questionnaire }\end{array}$ & 3 & 1954 & 7.6 & 7.83 & 7.37 & 565 & 585 & 8.68 & 5.78 & 50.2 \\
\hline $\begin{array}{c}\text { Performance of an } \\
\text { unskilled task }\end{array}$ & 8 & 13376 & 7.1 & 7.93 & 8.45 & 6536 & 5876 & 9.21 & 7.86 & 17.2 \\
\hline 'A re you R/L handed?' & 17 & 67545 & 8.8 & 8.68 & 7.63 & 32849 & 17229 & 7.80 & 6.17 & 26.4 \\
\hline W riting hand & 18 & 105169 & 9.1 & 8.33 & 6.89 & 51905 & 50884 & 7.97 & 5.73 & 39.1 \\
\hline
\end{tabular}


Table 4: Incidence of left-handedness in relation to number of items on questionnaire or inventory.

\begin{tabular}{|c|c|c|c|c|c|c|c|c|c|c||}
\hline $\begin{array}{c}\text { Number of items on } \\
\text { questionnaire }\end{array}$ & $\begin{array}{c}\text { Numbe } \\
\text { r of } \\
\text { studies }\end{array}$ & $\begin{array}{c}\text { Number } \\
\text { of } \\
\text { subjects }\end{array}$ & M edian & M ean & $\begin{array}{c}\text { Overall } \\
\text { incidence }\end{array}$ & M ales & Females & $\begin{array}{c}\text { Overall } \\
\text { incidence: } \\
\text { M al es }\end{array}$ & $\begin{array}{c}\text { Overall } \\
\text { incidence: } \\
\text { Females }\end{array}$ & $\begin{array}{c}\text { 100(M -F) } \\
------- \\
F\end{array}$ \\
\hline \hline $3-6$ & 10 & 40130 & 10.4 & 9.39 & 9.08 & 20103 & 18914 & 9.90 & 8.03 & 23.3 \\
\hline $7-10$ & 16 & 21246 & 8.6 & 10.33 & 8.01 & 6492 & 7342 & 8.84 & 7.57 & 16.8 \\
\hline $11-15$ & 18 & 27498 & 8.9 & 9.16 & 8.31 & 6341 & 6488 & 10.66 & 9.41 & 13.3 \\
\hline $16-49$ & 4 & 1751 & 8.9 & 9.05 & 8.17 & 594 & 906 & 10.94 & 6.16 & 77.6 \\
\hline $50+$ & 4 & 3059 & 9.0 & 8.8 & 9.15 & 1279 & 1378 & 11.00 & 7.42 & 48.2 \\
\hline
\end{tabular}


Table 5: Incidence of left-handedness in relation to number of response categories on each item of an inventory.

\begin{tabular}{|c||c|c|c|c|c|c|c|c|c|c|}
\hline $\begin{array}{c}\text { Number of response } \\
\text { categories on } \\
\text { questionnaire }\end{array}$ & $\begin{array}{c}\text { Numbe } \\
\text { r of } \\
\text { studies }\end{array}$ & $\begin{array}{c}\text { Number } \\
\text { of } \\
\text { subjects }\end{array}$ & M edian & M ean & $\begin{array}{c}\text { Overall } \\
\text { incidence }\end{array}$ & M ales & Females & $\begin{array}{c}\text { Overall } \\
\text { incidence: } \\
\text { M al es }\end{array}$ & $\begin{array}{c}\text { Overall } \\
\text { incidence: } \\
\text { Females }\end{array}$ & $\begin{array}{c}100(M-F) \\
----- \\
F\end{array}$ \\
\hline$<5$ & 20 & 51599 & 9.0 & 9.14 & 8.79 & 23127 & 21926 & 9.72 & 7.83 & 24.1 \\
\hline 5 & 27 & 33033 & 9.2 & 10.48 & 10.41 & 10424 & 11545 & 10.45 & 9.03 & 15.7 \\
\hline$>5$ & 2 & 2176 & 8.3 & 8.3 & 9.28 & - & - & - & - & - \\
\hline
\end{tabular}


Table 6: Incidence of left-handedness in relation to sampling method for obtaining subjects.

\begin{tabular}{|c|c|c|c|c|c|c|c|c|c|c|}
\hline Sampling methods & $\begin{array}{c}\text { Numbe } \\
\text { r of } \\
\text { studies }\end{array}$ & $\begin{array}{l}\text { Number } \\
\text { of } \\
\text { subjects }\end{array}$ & M edian & M ean & $\begin{array}{c}\text { Overall } \\
\text { incidence }\end{array}$ & M ales & Females & $\begin{array}{c}\text { Overall } \\
\text { incidence: } \\
\text { M ales }\end{array}$ & $\begin{array}{c}\text { Overall } \\
\text { incidence: } \\
\text { Females }\end{array}$ & $\begin{array}{c}100(M-F) \\
-\cdot F\end{array}$ \\
\hline Self-sel ected volunteers & 26 & 28897 & 9.8 & 10.31 & 10.02 & 10701 & 10879 & 10.80 & 8.99 & 20.1 \\
\hline Captive whole group & 28 & 164313 & 9.1 & 9.25 & 7.34 & 85445 & 67098 & 8.19 & 6.22 & 31.7 \\
\hline Random sample & 39 & 62409 & 9.0 & 8.66 & 8.05 & 25723 & 27141 & 9.05 & 7.19 & 25.9 \\
\hline $\begin{array}{c}\text { Indirect reporting by } \\
\text { others }\end{array}$ & 7 & 29046 & 6.7 & 6.63 & 7.39 & 7394 & 7056 & 7.16 & 5.61 & 27.6 \\
\hline
\end{tabular}


Table 7: Incidence of left-handedness in relation to estimated degree of bias in the selection of subjects.

\begin{tabular}{|c|c|c|c|c|c|c|c|c|c|c|}
\hline $\begin{array}{l}\text { Estimated degree of } \\
\text { bias }\end{array}$ & $\begin{array}{l}\text { Numbe } \\
\text { r of } \\
\text { studies }\end{array}$ & $\begin{array}{l}\text { Number } \\
\text { of } \\
\text { subjects }\end{array}$ & M edian & M ean & $\begin{array}{l}\text { Overall } \\
\text { incidence }\end{array}$ & $M$ ales & Females & $\begin{array}{c}\text { Overall } \\
\text { incidence: } \\
\text { M ales }\end{array}$ & $\begin{array}{l}\text { Overall } \\
\text { incidence: } \\
\text { Females }\end{array}$ & \begin{tabular}{c}
$100(M-F)$ \\
\hdashline$F$
\end{tabular} \\
\hline None & 10 & 101443 & 7.1 & 6.95 & 6.04 & 50682 & 50036 & 7.09 & 4.94 & 43.5 \\
\hline Slight & 42 & 121862 & 9.1 & 9.01 & 8.55 & 61822 & 46312 & 9.22 & 7.92 & 16.4 \\
\hline Possible & 35 & 47607 & 9.1 & 9.07 & 8.79 & 11417 & 10914 & 9.45 & 7.88 & 19.9 \\
\hline Probable & 13 & 13573 & 9.8 & 11.23 & 10.19 & 5342 & 4912 & 11.96 & 10.12 & 18.2 \\
\hline
\end{tabular}


Table 8: Incidence of left-handedness in relation to response rate, if known.

\begin{tabular}{|c|c|c|c|c|c|c|c|c|c|c|}
\hline Response rate & $\begin{array}{l}\text { Numbe } \\
\text { r of } \\
\text { studies }\end{array}$ & $\begin{array}{c}\text { Number } \\
\text { of } \\
\text { subjects }\end{array}$ & M edian & M ean & $\begin{array}{l}\text { Overall } \\
\text { incidence }\end{array}$ & M ales & Females & $\begin{array}{c}\text { Overall } \\
\text { incidence: } \\
\text { M ales }\end{array}$ & $\begin{array}{l}\text { Overall } \\
\text { incidence: } \\
\text { Females }\end{array}$ & \begin{tabular}{c}
$100(M-F)$ \\
\hdashline$F$
\end{tabular} \\
\hline $0-39 \%$ & 6 & 10575 & 8.5 & 7.88 & 10.10 & 4125 & 4683 & 12.20 & 9.75 & 25.1 \\
\hline $40-79 \%$ & 8 & 30481 & 8.2 & 8.80 & 6.24 & 13386 & 13369 & 5.63 & 4.66 & 25.9 \\
\hline $80-99 \%$ & 5 & 13675 & 10.3 & 9.32 & 9.28 & 6758 & 6917 & 10.01 & 8.56 & 13.7 \\
\hline $100 \%$ & 12 & 115795 & 7.5 & 7.12 & 6.28 & 65352 & 49719 & 7.31 & 4.90 & 49.2 \\
\hline
\end{tabular}


Table 9: Incidence of left-handedness in relation to sample size in study.

\begin{tabular}{|c|c|c|c|c|c|c|c|c|c|c|}
\hline Sample size & $\begin{array}{l}\text { Numbe } \\
r \text { of } \\
\text { studies }\end{array}$ & $\begin{array}{c}\text { Number } \\
\text { of } \\
\text { subjects }\end{array}$ & M edian & M ean & $\begin{array}{c}\text { Overall } \\
\text { incidence }\end{array}$ & $M$ ales & Females & $\begin{array}{c}\text { Overall } \\
\text { incidence: } \\
\text { M ales }\end{array}$ & $\begin{array}{c}\text { Overall } \\
\text { incidence: } \\
\text { Females }\end{array}$ & \begin{tabular}{c}
$100(M-F)$ \\
\hdashline
\end{tabular} \\
\hline$<250$ & 16 & 2880 & 9.4 & 10.70 & 10.21 & 1591 & 1421 & 10.71 & 9.20 & 16.4 \\
\hline $250-999$ & 37 & 2415 & 8.9 & 9.07 & 8.64 & 15664 & 14537 & 9.55 & 8.05 & 18.6 \\
\hline $1000-4999$ & 34 & 75680 & 9.3 & 8.74 & 8.44 & 44200 & 47412 & 9.63 & 7.66 & 25.7 \\
\hline$>4999$ & 13 & 181953 & 8.6 & 8.24 & 7.31 & 67808 & 48804 & 7.71 & 5.26 & 42.8 \\
\hline
\end{tabular}


Table 10: Incidence of left-handedness in relation to source of study.

\begin{tabular}{|c|c|c|c|c|c|c|c|c|c|c|}
\hline Source of study & $\begin{array}{l}\text { Numbe } \\
\text { r of } \\
\text { studies }\end{array}$ & $\begin{array}{l}\text { Number } \\
\text { of } \\
\text { subjects }\end{array}$ & M edian & M ean & $\begin{array}{l}\text { Overall } \\
\text { incidence }\end{array}$ & $M$ ales & Females & $\begin{array}{c}\text { Overall } \\
\text { incidence: } \\
\text { M ales }\end{array}$ & $\begin{array}{c}\text { Overall } \\
\text { incidence: } \\
\text { Females }\end{array}$ & $\begin{array}{c}100(M-F) \\
-F\end{array}$ \\
\hline Systematic search & 48 & 79630 & 9.1 & 10.30 & 9.16 & 24106 & 24991 & 10.49 & 8.75 & 19.9 \\
\hline Secondary references & 34 & 176816 & 7.8 & 8.01 & 7.24 & 92742 & 75221 & 8.12 & 6.03 & 34.7 \\
\hline $\begin{array}{l}\text { Personal collection/ } \\
\text { U npublished }\end{array}$ & 18 & 28219 & 9.4 & 8.04 & 7.21 & 12415 & 11962 & 7.65 & 6.53 & 17.2 \\
\hline
\end{tabular}


Table 11: Incidence of left-handedness in relation to the assessment of the main purpose of the study.

\begin{tabular}{|c|c|c|c|c|c|c|c|c|c|c|}
\hline M ain purpose of study & $\begin{array}{l}\text { Numbe } \\
\text { r of } \\
\text { studies }\end{array}$ & $\begin{array}{c}\text { Number } \\
\text { of } \\
\text { subjects }\end{array}$ & M edian & M ean & $\begin{array}{l}\text { Overall } \\
\text { incidence }\end{array}$ & M ales & Females & $\begin{array}{c}\text { Overall } \\
\text { incidence: } \\
\text { M ales }\end{array}$ & $\begin{array}{l}\text { Overall } \\
\text { incidence: } \\
\text { Females }\end{array}$ & $\begin{array}{c}100(M-F) \\
F\end{array}$ \\
\hline Handedness & 57 & 113791 & 8.9 & 9.30 & 8.00 & 41721 & 38256 & 8.36 & 7.03 & 18.9 \\
\hline L ateralisation & 20 & 39749 & 10.1 & 9.27 & 10.00 & 16192 & 15748 & 11.90 & 10.02 & 18.8 \\
\hline Other measures & 10 & 13247 & 9.9 & 9.10 & 9.40 & 6018 & 5624 & 10.00 & 8.02 & 24.7 \\
\hline Multivariate & 13 & 117878 & 7.2 & 8.07 & 6.63 & 65332 & 52546 & 7.65 & 5.29 & 44.6 \\
\hline
\end{tabular}


Table 12: Incidence of left-handedness in relation to the year in which the study was carried out (or year of publication if year of study not stated).

\begin{tabular}{|c|c|c|c|c|c|c|c|c|c|c|}
\hline $\begin{array}{l}\text { Y ear of study or } \\
\text { year of publication }\end{array}$ & $\begin{array}{c}\text { Numbe } \\
r \text { of } \\
\text { studies }\end{array}$ & $\begin{array}{l}\text { Number } \\
\text { of } \\
\text { subjects }\end{array}$ & M edian & M ean & $\begin{array}{l}\text { Overall } \\
\text { incidence }\end{array}$ & M ales & Females & $\begin{array}{c}\text { Overall } \\
\text { incidence: } \\
\text { M ales }\end{array}$ & $\begin{array}{l}\text { Overall } \\
\text { incidence: } \\
\text { Females }\end{array}$ & \begin{tabular}{c}
$100(M-F)$ \\
\hdashline$F$
\end{tabular} \\
\hline $1900-39$ & 9 & 36676 & 7.5 & 7.53 & 8.42 & 17381 & 13813 & 8.81 & 7.59 & 16.1 \\
\hline $1940-69$ & 11 & 109412 & 7.0 & 7.43 & 6.02 & 60395 & 46370 & 7.11 & 4.57 & 55.6 \\
\hline $1970-79$ & 38 & 61550 & 9.2 & 8.46 & 9.31 & 23978 & 24439 & 10.69 & 8.80 & 21.5 \\
\hline $1980-89$ & 42 & 77027 & 9.2 & 10.49 & 8.75 & 27509 & 27555 & 9.53 & 7.93 & 20.2 \\
\hline
\end{tabular}


Table 13: Incidence of left-handedness in relation to estimated year of birth of subjects.

\begin{tabular}{|c|c|c|c|c|c|c|c|c|c|c|}
\hline Y ear of birth & $\begin{array}{l}\text { Numbe } \\
\text { r of } \\
\text { studies }\end{array}$ & $\begin{array}{l}\text { Number } \\
\text { of } \\
\text { subjects }\end{array}$ & M edian & M ean & $\begin{array}{l}\text { Overall } \\
\text { incidence }\end{array}$ & M ales & Females & $\begin{array}{c}\text { Overall } \\
\text { incidence: } \\
\text { M ales }\end{array}$ & $\begin{array}{l}\text { Overall } \\
\text { incidence: } \\
\text { Females }\end{array}$ & \begin{tabular}{c}
$100(M-F)$ \\
\hdashline$F$
\end{tabular} \\
\hline Pre-1910 & 8 & 27697 & 4.9 & 6.43 & 4.65 & 13355 & 11005 & 4.58 & 3.36 & 36.3 \\
\hline $1910-39$ & 10 & 39573 & 7.8 & 8.11 & 9.36 & 25827 & 11585 & 9.71 & 9.02 & 7.6 \\
\hline $1940-59$ & 26 & 115129 & 9.8 & 8.78 & 6.41 & 53324 & 52627 & 7.38 & 5.40 & 36.7 \\
\hline $1960-69$ & 26 & 6.0345 & 10.1 & 11.51 & 9.96 & 21302 & 20327 & 11.45 & 9.68 & 18.3 \\
\hline $1970-89$ & 8 & 8576 & 9.1 & 9.67 & 9.35 & 3357 & 3586 & 11.01 & 8.60 & 28.0 \\
\hline
\end{tabular}


Table 14: Incidence of left-handedness in relation to estimated age of subjects at time of study.

\begin{tabular}{|c|c|c|c|c|c|c|c|c|c|c|}
\hline A ge of subjects & $\begin{array}{c}\text { Numbe } \\
r \text { of } \\
\text { studies }\end{array}$ & $\begin{array}{c}\text { Number } \\
\text { of } \\
\text { subjects }\end{array}$ & M edian & M ean & $\begin{array}{l}\text { Overall } \\
\text { incidence }\end{array}$ & M ales & Females & $\begin{array}{c}\text { Overall } \\
\text { incidence: } \\
\text { M ales }\end{array}$ & $\begin{array}{c}\text { Overall } \\
\text { incidence: } \\
\text { Females }\end{array}$ & $\begin{array}{c}100(M-F) \\
-F\end{array}$ \\
\hline $7-14$ & 16 & 128712 & 9.2 & 9.33 & 7.60 & 64536 & 62244 & 8.68 & 6.44 & 34.8 \\
\hline $15-24$ & 47 & 86382 & 9.8 & 10.41 & 8.83 & 36502 & 20527 & 9.39 & 8.90 & 5.5 \\
\hline $25-34$ & 3 & 9293 & 11.0 & 9.33 & 5.46 & 4588 & 4508 & 5.92 & 4.73 & 25.2 \\
\hline $35-44$ & 3 & 1941 & 6.9 & 6.90 & 7.10 & 591 & 546 & 7.83 & 5.45 & 43.7 \\
\hline $45-54$ & 7 & 18645 & 6.7 & 5.91 & 4.23 & 8517 & 8486 & 4.45 & 3.61 & 23.3 \\
\hline $55-64$ & 1 & 4950 & 5.4 & 5.40 & 5.40 & 2431 & 2519 & 5.70 & 5.00 & 14.0 \\
\hline $65-74$ & 1 & 497 & 3.2 & 3.20 & 3.20 & - & - & - & - & - \\
\hline $75+$ & - & - & - & - & - & - & - & - & - & - \\
\hline
\end{tabular}


Table 15: Incidence of left-handedness in relation to geographical region of study.

\begin{tabular}{|c|c|c|c|c|c|c|c|c|c|c|}
\hline Continent & $\begin{array}{c}\text { Numbe } \\
\text { r of } \\
\text { studies }\end{array}$ & $\begin{array}{c}\text { Number } \\
\text { of } \\
\text { subjects }\end{array}$ & M edian & M ean & $\begin{array}{c}\text { Overall } \\
\text { incidence }\end{array}$ & M ales & Females & $\begin{array}{c}\text { Overall } \\
\text { incidence: } \\
\text { M al es }\end{array}$ & $\begin{array}{c}\text { Overall } \\
\text { incidence: } \\
\text { Females }\end{array}$ & $\begin{array}{c}100(M-F) \\
---F^{F} \\
F\end{array}$ \\
\hline \hline North A merica & 45 & 112531 & 9.1 & 9.49 & 8.52 & 51545 & 36095 & 8.95 & 7.48 & 19.7 \\
\hline South A merica & 2 & 1789 & 10.2 & 10.20 & 11.23 & - & - & - & - & - \\
\hline Europe & 36 & 133401 & 8.9 & 9.13 & 6.71 & 61748 & 60767 & 7.51 & 5.50 & 36.5 \\
\hline A sia & 8 & 30234 & 4.4 & 6.43 & 9.41 & 13035 & 12140 & 11.24 & 9.61 & 17.0 \\
\hline A ustralasia/ Pacific & 6 & 6142 & 10.5 & 10.10 & 8.16 & 2138 & 2413 & 9.82 & 8.70 & 12.9 \\
\hline A frica & 3 & 568 & 9. & 7.73 & 7.57 & - & - & - & - & - \\
\hline
\end{tabular}


Table 16. Degree of handedness in 2028 applicants to medical school (M cM anus, 1986, unpublished). A pplicants were asked to state the hand used for writing on a five-point scale.

\begin{tabular}{|c|c|c|c|}
\hline Classification & Males & Females & Chi-square \\
\hline A Iways Right & $968(87.5 \%)$ & $774(83.9 \%)$ & \\
\hline Usually Right & $15(1.4 \%)$ & $47(5.1 \%)$ & \\
\hline Either & $3(0.3 \%)$ & $3(0.3 \%)$ & \\
\hline Usually Left & $6(0.5 \%)$ & $9(1.0 \%)$ & \\
\hline A Iways L eft & $114(10.3 \%)$ & $89(9.7 \%)$ & \\
\hline Total & 1106 & 922 & \\
\hline $\mathrm{pWR}$ & 0.015 & 0.057 & \\
\hline pW L & 0.050 & 0.092 & \\
\hline $\mathrm{pW}$ & 0.022 & 0.064 & $22.91, p<.001$ \\
\hline $\mathrm{pL}$ & 0.111 & 0.110 & $0.014, p=.905$ \\
\hline
\end{tabular}


Figure 1: Shows the overall incidence of left-handedness reported in 100 study populations, according to the criterion used for defining left-handedness. It should be noted that the 15 studies using a Right-M ixed-L eft classification are entered into the figure twice (using different shading), once for an incidence of left-handedness of $L /(R+M+L)$ and once for an incidence calculated as $(L+M) /(R+M+L)$.

\section{Figure 1 \\ Incidence of left-handedness}

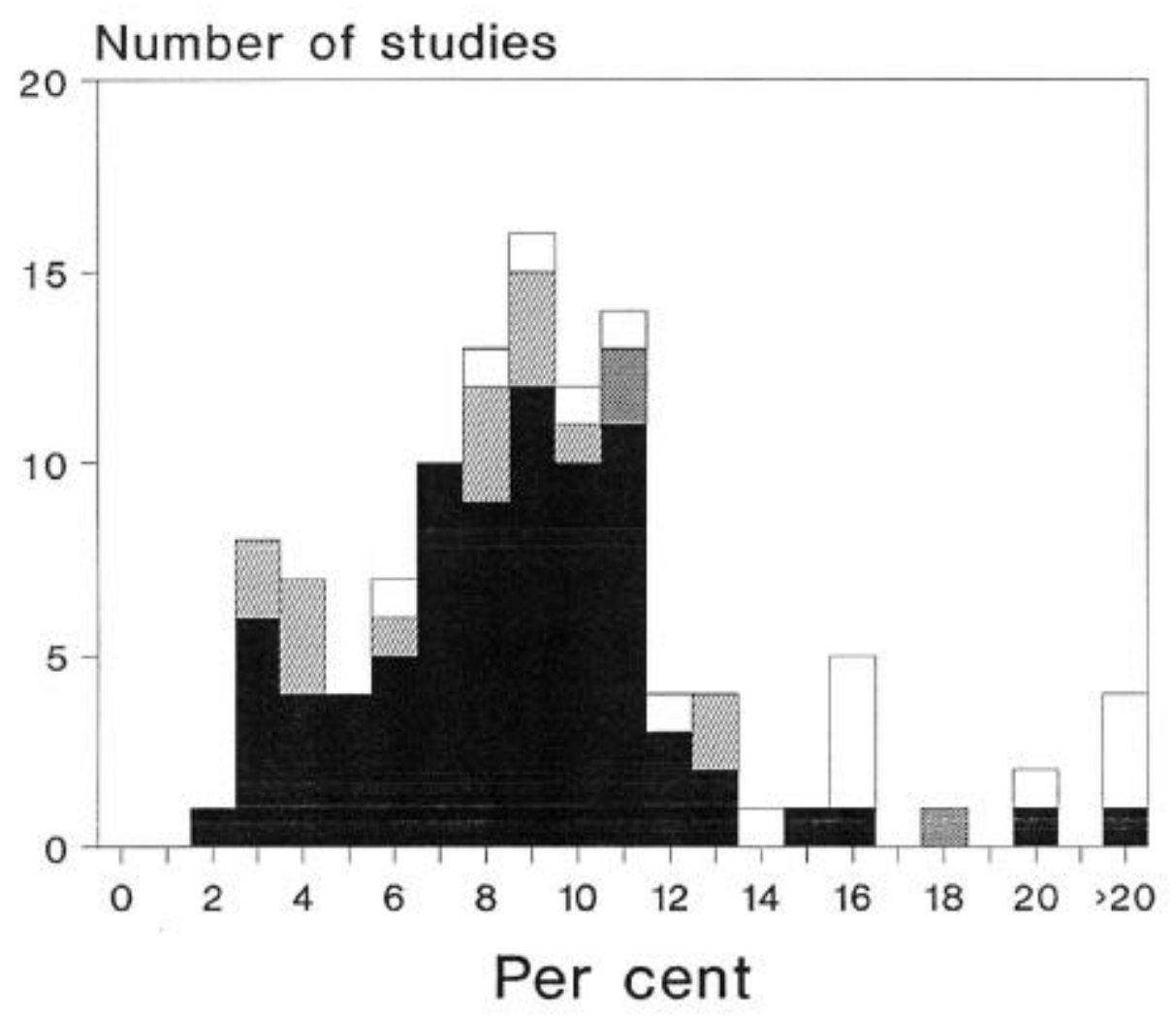

$\mathrm{L} /(\mathrm{L}+\mathrm{R})$

DR/(R+NR)

ㄴ. $L /(L+M+R)$

$\square(L+M) /(L+M+R)$

Figure 2: Shows the difference in incidence of handedness in male and females for 62 study populations. The percentage excess of left-handedness in males is calculated as $100 *(\mathrm{M}-\mathrm{F}) / \mathrm{F}$. 
Figure 2: Shows the difference in incidence of handedness in male and females for 62 study populations. The percentage excess of left-handedness in males is calculated as $100 *(\mathrm{M}-\mathrm{F}) / \mathrm{F}$.

\section{Figure 2 Sex differences}

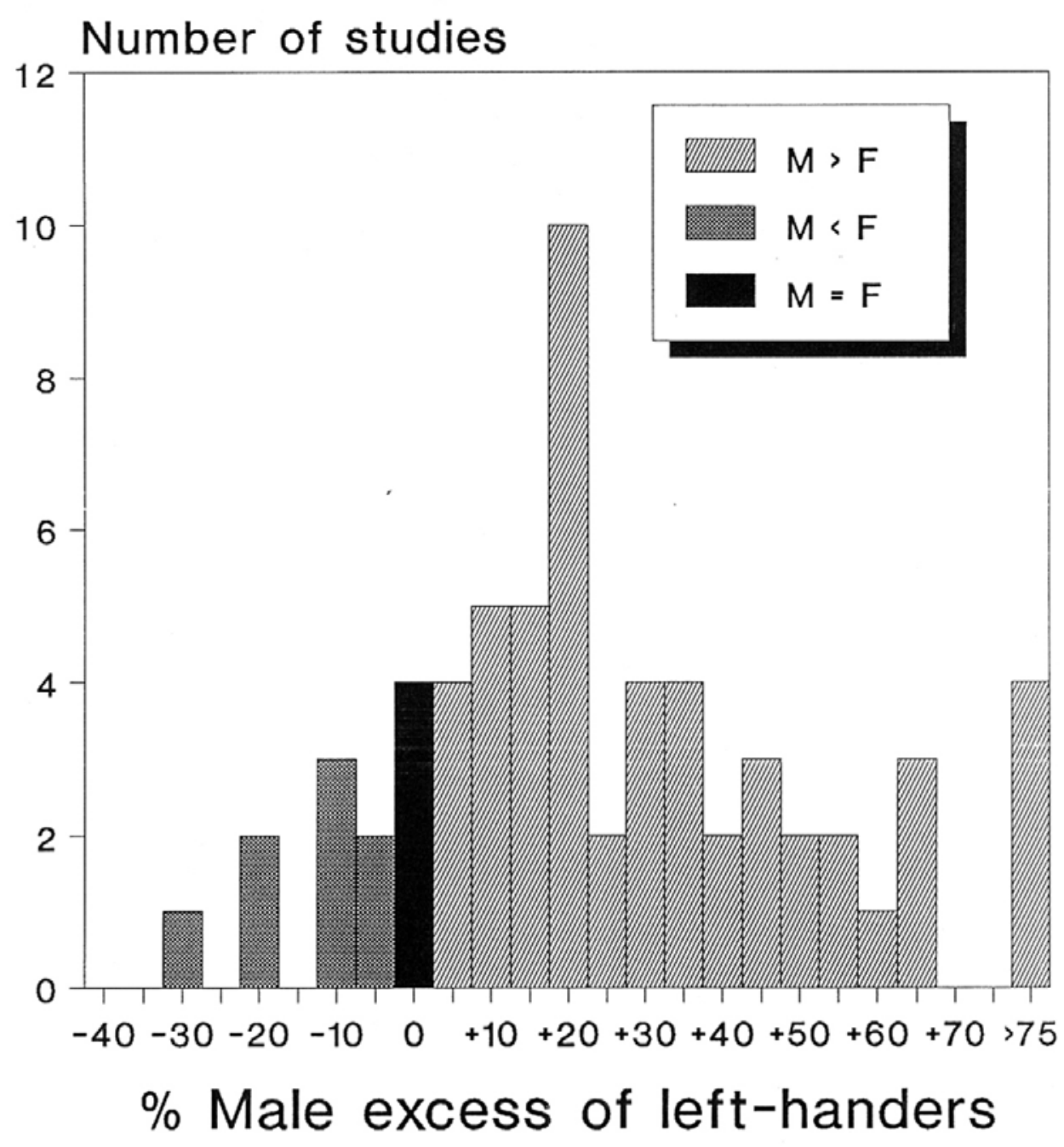


A nnett, M. (1973b). Handedness in families. A nnals of Human Genetics, 37, 93-105.

A nnett, M . (1976). A coordination of hand preference and skill replicated. British Lournal of Psychology, 67, 587-592.

A nnett, M . (1979c). Family handedness in three generations predicted by the right shift theory. A nnals of Human Genetics, 42, 479-491.

A nnett, M . (1985). Left, right, hand and brain: the right shift theory. N ew J ersey: Lawrence Erlbaum.

A nnett, M . \& A nnett, J. (1991). Handedness for eating in gorillas. Cortex, 27, 269-275.

A rdila, A., A rdila, O., B ryden, M. P., Ostrosky, F., Rosselli, M., \& Steenhuis, R. E. (1989). Effects of cultural background and education on handedness. Neuropsychologia, 27. 893-897.

A shton, G. C. (1982b). Handedness: an al ternative hypothesis. B ehavior Genetics, 12 , 125-147.

Badian, N. A . (1983). Birth order, maternal age, season of birth, and handedness. Cortex, $19,451-463$.

Bahn, P. G. (1989). E arly teething troubles. Nature, 337, 693-693.

Beckman, L. \& Elston, R. (1962a). Data on bilateral variation in man: handedness, hand clasping and arm folding in Swedes. Human Biology, 34, 99-103.

Benson, D. F. (1986). A phasia and the lateral ization of language. Cortex, 22, 71-86.

Berker, E. A., B erker, A . H., \& Smith, A . (1986). Translation of Broca's 1865 report: Localisation of speech in the third left frontal convolution. A rchives of Neurology, 43, 10651072.

B eukelaar, L. J . \& K roonenberg, P. M . (1986). Changes over time in the relationship between hand preference and writing hand among left-handers. Neuropsychologia, 24, 301303.

Birkett, P. (1981c). Familial handedness and sex differences in strength of hand preference. Cortex, 17, 141-146.

Bishop, D. V . M . (1986). Is there a link between handedness and hypersensitivity? Cortex, 22, 289-296.

Bishop, D. V. M . (1990). Handedness and developmental disorder. Oxford: Blackwell. Bonvillian, J. D., Orlansky, M. D., \& Garland, J. B . (1982). Handedness patterns in deaf persons. Brain and Cognition, 1, 141-157. 
Brackenridge, C. J. (1981). Secular variation in handedness over ninety years. Neuropsychologia, 19, 459-462.

Bradshaw, J. L. (1991). A nimal asymmetry and human heredity: dextrality, tool use and language in evolution - 10 years after W al ker (1980). British Journal of Psychology, 82, 39-59.

Briggs, G. G. \& Nebes, R. D. (1975b). Patterns of hand preference in a student population. Cortex, 11, 230-238.

B rito, G. N. O., B rito, L. S. O., Paumgartten, F. J. R., \& Lins, M. F. C. (1989a). Lateral preferences in B razilian adults: an analysis with the Edinburgh Inventory. Cortex, 25, 403415.

B roca, P. (1865). Sur le siège de la faculté du langage articulé. Bulletin de la Société d'A nthropologie de Paris, 6, 377-393.

Brooker, R. J., Lehmann, R. A. W ., Heimbuch, R. C., \& Kidd, K. K. (1981). Hand usage in a colony of Bonnett monkeys, M acaca radiata. Behavior Genetics, 11, 49-56.

B ryden, M . P. (1977b). M easuring handedness with inventories. Neuropsychologia, $15,617-624$.

Bryden, M . P. (1982). L aterality: functional asymmetry in the intact brain. N ew Y ork: A cademic Press.

Bryden, M. P. (1988a). A n overview of the dichotic listening procedure and its relation to cerebral organization. In K.Hugdahl (Ed.), Handbook of Dichotic Listening: Theory, methods and research (pp. 1-43). London: John W iley.

Bryden, M. P. (1988b). Cerebral specialization: Clinical and experimental assessment. In F.Boller \& J. Grafman (Eds.), Handbook of N europsychology, V olume 1. (pp. 143-159). A msterdam: Elsevier.

Buchtel, H. A . \& R ueckert, L. (1984). Hand posture in writing: possible artifacts from self-report. Cortex, 20, 435-439.

Burgess, J. W . \& Villablanca, J. R. (1986). Recovery of function after neonatal or adult hemispherectomy in cats. II: L imb bias and development, paw usage, locomotion and rehabilitative effects of exercise. Behavioural Brain Research, 20, 1-18.

Byrne, B. (1974). Handedness and musical ability. British J ournal of Psychology, 65, 279-281.

Byrne, R. W . \& Byrne, J. M. (1991). Hand preferences in the skilled gathering tasks of mountain gorillas (G orilla g. berengei). Cortex, 27, 521-546. 
Calvin, W. H. (1982). Did throwing stones shape hominid brain evolution? Ethology and Sociobiology, 3, 115-124.

Carrothers, G. E. (1947). Left-handedness among school pupils. A merican School Board Journal, 114, 17-19.

Carter-Saltzmann, L. (1981). Biological and socio-cultural effects on handedness: comparison between biological and adoptive families. Science, 209, 1263-1265.

Cavalli-Sforza, L. L. \& Bodmer, W. F. (1971). The genetics of human populations. San Francisco: W.H.Freeman.

Chamberlain, H. D. (1928). The inheritance of left-handedness. Цournal of Heredity, 19, 557-559.

Chapman, J. P., Chapman, L. J ., \& A llen, J. A . (1987). The measurement of foot preference. Neuropsychologia, 25, 579-584.

Chapman, L. J . \& Chapman, J. P. (1987). The measurement of handedness. Brain and Cognition, 6, 175-183.

Charles, D. (1991). Left-handers don't die young after all. New Scientist, 130, 21-21.

Clark, M . M . (1957). Left-handedness: L aterality characteristics and their educational implications. London: U niversity of L ondon Press.

Cole, J. (1955). Paw preferences in cats related to hand preferences in animals and M an. Lournal of Comparative and Physiological Psychology, 48, 137-140.

Collins, E. H. (1961). The concept of relative limb dominance. Human Biology, 33, 293-318.

Collins, R. L. (1985). On the inheritance of direction and degree of asymmetry. In S.D.Glick (Ed.), Cerebral lateralization in non-human species (pp. 41-71). N ew Y ork: A cademic Press.

Connolly, K . \& Bishop, D. V . M . (1992). The measurement of handedness: a crosscultural comparison of samples from England and Papua New Guinea. N europsychologia, 30, 13-26.

Coren, S. (1989). Left-handedness and accident-related injury risk. A merican J ournal of Public Health, 79, 1040-1041.

Coren, S. \& Hal pern, D. F. (1991). Left-handedness: a marker for decreased survival fitness. Psychological Bulletin, 109, 90-106.

Coren, S. \& Porac, C. (1977c). Fifty centuries of right-handedness: the historical record. Science, 198, 631-632. 
Coren, S. \& Porac, C. (1980). Birth factors and laterality: effects of birth order, parental age, and birth stress on four indices of Iateral preference. Behavior Genetics, 10, 123138.

Cornell, E. \& M cM anus, I. C. (1992). Differential survey response rates in right and left-handers. B ritish J ournal of Psychology, 83, 39-43.

Cornford, J. M . (1986). Specialised resharpening techniques and evidence of handedness. In P.Cal low \& J. M . Cornford (E ds.), L a Cotte de St. B relade 1961-1978: Excavations by C.B.M. M cBurney (pp. 337-362). Norwich: Geo B ooks.

Cosi, V ., Citterio, A ., \& Pasquino, C. (1988). A study of hand preference in myasthenia gravis. Cortex, 24, 573-577.

Crovitz, H. F. \& Zener, K . (1962b). A group test for assessing hand and eyedominance. A merican Journal of Psychology, 75, 271-276.

Damasio, A. R. (1992). A phasia. New England J ournal of M edicine, 326, 531-539.

Dawson, J. L. M . B . (1972). Temne A runta hand-eye dominance and cognitive style. International J ournal of Psychology, 7, 219-233.

de Castro, J. M . B., Bromage, T. G., \& Jalvo, Y . F. (1988). Buccal striations on fossil human anterior teeth: evidence of handedness in the middle and early U pper Pleistocene. Lournal of Human Evolution, 17, 403-412.

Dellatolas, G., Tubert, P., Castresana, A ., M esbah, M ., Giallonardo, T., L azaratou, H., \& Lellouch, J. (1991). A ge and cohort effects in adult handedness. N europsychologia, 29, 255-261.

Downey, J. E. (1927). Types of dextrality and their implications. A merican J ournal of Psychology, 38, 317-367.

Durost, W . N . (1935). The development of a battery of objective group tests of manual laterality with the results of application to 1300 children. Genetic Psychology M onographs, 16, 224-235.

Dusek, C. D. \& Hicks, R. A . (1980). M ultiple birth risk factors and handedness in elementary school children. Cortex, 16, 471-478.

Ellis, S. J., Ellis, P. J., \& M arshall, E. (1988). Hand preferences in a normal population. Cortex, 24, 157-163.

Falek, A. (1959). Handedness: a family study. A merican J ournal of Human Genetics, 2, 52-62. 
Fleminger, J . J ., Dalton, E., \& Standage, K. F. (1977). A ge as a factor in the handedness of adults. Neuropsychologia, 15, 471-473.

Frost, G. T. (1980). Tool behavior and the origins of Iaterality. Lournal of Human Evolution, 9, 447-459.

Geschwind, N. \& Levitsky, W . (1968). Human brain: left-right asymmetries in temporal speech region. Science, 161, 186-187.

Gill berg, C., W al denström, E., \& Rasmussen, P. (1984). Handedness in Swedish 10year olds: some background and associated factors. Journal of Child Psychology and Psychiatry, 25, 421-432.

Glass, G. V . (1977a). Integrating findings: the meta-analysis of research. Review of Research in Education, 5, 351-379.

Gur, R. E. \& Gur, R. C. (1977). Sex differences in the relations among handedness, sighting-dominance and eye-acuity. N europsychologia, 15, 585-590.

Hal pern, D. F. \& Coren, S. (1988b). Do right-handers live longer? Nature, 333, 213213.

Halpern, D. F. \& Coren, S. (1990b). L aterality and longevity: is left-handedness associated with a younger age at death? In S.Coren (E d.), Left-handedness: B ehavioral implications and anomalies (pp. 509-545). A msterdam: N orth-H olland.

Hardyck, C., Goldman, R., \& Petrinovich, L. (1975a). Handedness and sex, race, and age. Human Biology, 47, 369-375.

Hardyck, C., Petrinovich, L. F., \& Goldman, R. D. (1976b). Left-handedness and cognitive deficit. Cortex, 12, 266-279.

Harrington, A . (1987). M edicine, mind, and the double brain; a study in nineteenthcentury thought. Princeton, NJ : Princeton University Press.

Harris, L. J. (1989). Footedness in parrots: three centuries of research, theory, and mere surmise. Canadian Journal of Psychology, 43, 369-376.

Harris, L. J . (1990). Cultural influences on handedness: historical and contemporary theory and evidence. In S.Coren (Ed.), L eft-handedness: Behavioral implications and anomalies (pp. 195-258). A msterdam: N orth-Holland.

Harris, L. J . Do left-handers die sooner than right handers? A commentary on Coren and $\mathrm{H}$ alpern's 'L eft-handedness: a marker for decreased survival fitness'. Psychological Bulletin (in press). 
Harris, L. J . \& Carlson, D. F. (1988). Pathological left-handedness: an analysis of theories and evidence. In D.L.M olfese \& S. J. Segalowitz (E ds.), Brain lateralization in children (pp. 289-372). N ew Y ork: Guilford Press.

Hatta, T. \& Nakatsuka, Z. (1976d). N ote on hand preference of J apanese people. Perceptual and M otor Skills, 42, 530-530.

Hebben, N., B enjamins, D., \& M ilberg, W. P. (1981). The relationship among handedness, sighting dominance and acuity dominance in el ementary school children. Cortex, 17, 441-446.

Hedges, L. V. \& Olkin, I. (1985a). Statistical methods for meta-analysis. Orlando, Florida: A cademic Press.

Heim, A. W . \& W atts, K. P. (1976c). Handedness and cognitive bias. Quarterly Journal of Experimental Psychology, 28, 355-360.

Heinlein, A . (1929). A study of detrality in children. Pedagogical Seminary and Journal of General Psychology, 36, 91-119.

Hécaen, H.\& Dubois, J . (1969). La naissance de la neuropsychologie du langage (1825-1865). Paris: Flammarion.

Hécaen, H. \& Lanteri-Laura, G. (1977). Evolution des connaissances et des doctrines sur les localisations cérébral es. Paris: Desclée de Brouwer.

Hicks, R. A ., Dusek, C., Larsen, F., Williams, S., \& Pellegrini, R. J . (1980). Birth complications and the distribution of handedness. Cortex, 16, 483-486.

Hicks, R. A . \& Dusek, C. M . (1980). The handedness distributions of gifted and nongifted children. Cortex, 16, 479-481.

Hicks, R. A., Pellegrini, R. J., \& Evans, E. A . (1978). Handedness and birth risk. Neuropsychologia, 16, 243-245.

Hill, A., W ard, S., Deino, A., Curtis, G., \& Drake, R. (1992). Earliest H omo. Nature, 355, 719-722.

Hull, C. J. (1936). A study of Iaterality test items. Journal of Experimental Education, 4, 287-290.

Hunter, J. E. \& Schmidt, F. L. (1990a). M ethods of meta-analysis. N ewbury Park, California: Sage.

Jarman, P. J . (1972). The development of a dermal shield in impala. Lournal of Zoology, 166, 349-356. 
J ones, B. \& Bell, J. (1980a). Handedness in engineering and psychology students.

Cortex, 16, 521-525.

Karpinos, B. D. \& Grossman, H. A. (1953). Prevalence of left-handedness among selective service registrants. Human Biology, 25, 36-49.

Kirk, S. A . (1935). Hemispheric cerebral dominance and hemispheric equipotentiality. Comparative Psychological M onographs, 11, 1-41.

K obyliansky, E., M icle, S., \& A rensburg, B . (1978). Handedness, hand-clasping and arm-folding in Israeli males. A nnals of Human Biology, 5, 247-251.

Koch, H. L., Carrington, E., Herring, A., Reed, R., Shaw, W. R., \& W alling, R. (1933). A study of the nature, measurement, and determination of hand preference. Genetic Psychology M onographs, 13, 117-190.

K omai, T. \& Fukuoka, G. (1934). A study on the frequency of left-handedness and left-footedness among J apanese school children. Human Biology, 6, 33-41.

Lansky, L. M ., Feinstein, H., \& Peterson, J. M . (1988). Demography of handedness in two samples of randomly selected adults ( $N=2083)$. Neuropsychologia, $26,465-477$.

Leiber, L. \& Axelrod, S. (1981a). Intra-familial learning is only a minor factor in manifest handedness. N europsychologia, 19, 273-288.

Leiber, L. \& A xelrod, S. (1981b). Not all sinistrality is pathological. Cortex, 17, 259272.

Levander, M . \& Schalling, D. (1988). Hand preference in a population of Swedish college students. Cortex, 24, 149-156.

Levy, J . (1974). Psychobiological implications of bilateral asymmetry. In S.J .Dimond \& J. G. B eaumont (Eds.), Hemisphere function in the human brain (pp. 121-183). N ew Y ork: J ohn Wiley.

Levy, J. (1976). A review of evidence for a genetic component in the determination of handedness. B ehavior Genetics, 6, 429-453.

Lewin, R. (1986). Dexterous early hominids. Science, 231, 115-115.

Liederman, J. \& Heal ey, J. M . (1986). Independent dimensions of hand preference: reliability of the factor structure and the handedness inventory. A rchives of Clinical Neuropsychology, 1, 371-386.

Lopez, B. (1986). A rctic dreams: imagination and desire in a northern landscape. New Y ork: Charles Scribner. 
M acN eilage, P. F., Studdert-K ennedy, M . G., \& Lindblom, B . (1987). Primate handedness reconsidered. B ehavioral and Brain Sciences, 10, 247-303.

M aehara, K., N egishi, N., T sai, A., Otsuki, N., Suzuki, S., Takahashi, T., \& Sumiyoshi, Y . (1988). Handedness in the J apanese. Developmental Neuropsychology, 4, 117-127.

M archant, L. F. \& M cGrew, W. C. (1991). L aterality of function in apes: a metaanalysis of methods. Journal of Human Evolution, 21, 425-438.

M arks, J. S. \& Williamson, D. F. (1991). Left-handedness and life expectancy. N ew England J ournal of M edicine, 325, 1042-1042.

M ascie-Taylor, C. G. N. (1981). Hand preference and personality traits. Cortex, 17, 319-322.

M cF arland, K . \& A nderson, J . (1980). Factor stability of the Edinburgh Handedness Inventory as a function of the test-retest performance, age and sex. B ritish Journal of Psychology, 71, 135-142.

M cGlone, J. (1980b). Sex differences in the human brain: a critical survey. Behavioral and Brain Sciences, 3, 215-263.

M cGrew, W . C. \& M archant, L. F. (1992). Chimpanzees, tools and termites: hand preference or handedness? Current A nthropology, 33, 114-119.

M cM anus, I. C. (1980). Handedness in twins: a critical review. Neuropsychologia, 18, 347-355.

M cM anus, I. C. (1983a). Pathological left-handedness: Does it exist? Journal of Communication Disorders, 16, 315-344.

M cM anus, I. C. (1983b). The interpretation of Iaterality. Cortex, 19, 187-214.

M CM anus, I. C . (1985a). Handedness, language dominance and aphasia: a genetic model. Psychological M edicine, M onograph Supplement No.8.

M cM anus, I. C. (1985c). On testing the right shift theory: a reply to A nnett. British Journal of Psychology, 76, 31-34.

M cM anus, I. C. (1985b). Right- and left-hand skill: failure of the right shift model. British J ournal of Psychology, 76, 1-16.

M cM anus, I. C. (1986a). Book review: 'Left side, right side: A review of laterality research' (B eaton, A .). British J ournal of Psychology, 77, 419-421.

M cM anus, I. C. (1991). The inheritance of left-handedness. In G.R.B ock \& J. M arsh (Eds.), Biological asymmetry and handedness (Ciba foundation symposium 162) (pp. 251281). Chichester: Wiley. 
M cM anus, I. C. \& B ryden, M. P. (1992). The genetics of handedness, cerebral dominance and Iateralization. In I.Rapin \& S. J. Segalowitz (Eds.), $\underline{\text { Handbook of }}$ Neuropsychology, V olume 6, Section 10: Child neuropsychology (Part 1) (pp. 115-144). A msterdam: Elsevier.

M cM anus, I. C. \& Bryden, M . P. (1993a). Handedness on Tristan da Cunha: The genetic consequences of social isolation. International Journal of Psychology, 28, 831-843.

M cM anus, I. C. \& Bryden, M. P. (1993b). The neurobiology of handedness, language and cerebral dominance: A model for the molecular genetics of behaviour. In M .H.J ohnson (Ed.), Brain development and cognition: A reader (pp. 679-702). Oxford: B lackwell.

M cM anus, I. C. \& M ascie-Taylor, C. G. N. (1979). Hand-clasping and arm-folding: a review and a genetic model. A nnals of Human Biology, 6, 527-558.

M cM anus, I. C., M urray, B ., Doyle, K ., \& B aron-Cohen, S. (1992). Handedness in childhood autism shows a dissociation of skill and preference. Cortex, $28,373-381$.

M cM anus, I. C., Shergill, S., \& Bryden, M . P. (1993). A nnett's theory that individuals heterozygous for the right shift gene are intellectually advantaged: Theoretical and empirical problems. British J ournal of Psychology, 84, 517-537.

M cM anus, I. C., Sik, G., Cole, D. R., M ellon, A. F., Wong, J., \& K loss, J. (1988c). The development of handedness in children. British J ournal of Developmental Psychology, 6, 257273.

M eans, L. W . \& W alters, R. E. (1982). Sex, handedness and asymmetry of hand and foot length. Neuropsychologia, 20, 715-719.

M erckel bach, H., de R uiter, C., \& Olff, M . (1989). Handedness and anxiety in normal and clinical populations. Cortex, 25, 599-606.

M errell, D. J. (1957). Dominance of hand and eye. Human Biology, 29, 314-328.

M ichel, G. F. \& Harkins, D. A . (1985). Concordance of handedness between teacher and student facilitates learning manual skills. Lournal of Human Evolution, 14, 597-601.

Morgan, M . J . \& M cM anus, I. C. (1988). The relationship between brainedness and handedness. In F.C.R ose, R. W hurr, \& M. Wyke (Eds.), A phasia (pp. 85-130). London: W hurr Publishers.

Nachson, I. \& Denno, D. (1986b). Birth order and lateral preferences. Cortex, 22, 567 578.

Nachson, I. \& Denno, D. (1987). Birth stress and lateral preferences. Cortex, 23, 45-58. 
Nachson, I., Denno, D., \& A urand, S. (1983). L ateral preferences of hand, eye and foot: relation to cerebral dominance. International J ournal of Neuroscience, 18, 1-10.

Neale, M . C. (1988). Handedness in a sample of volunteer twins. Behavior Genetics, 18, 69-79.

Newcombe, F. \& Ratcliff, G. (1973a). Handedness, speech lateralisation and ability. Neuropsychologia, 11, 399-407.

Newcombe, F. G., Ratcliff, G. G., Carrivick, P. J., Hiorns, R. W., Harrison, G. A., \& Gibson, J. B . (1975). Hand preference and I.Q. in a group of Oxfordshire villages. A nnals of Human Biology, 2, 235-242.

Oldfield, R. C. (1969). Handedness in musicians. British J ournal of Psychology, 60, 91-99.

Oldfield, R. C. (1971). The assessment and analysis of handedness: the Edinburgh inventory. Neuropsychologia, 9, 97-113.

Orne, M. T. (1962). On the social psychology of the psychological experiment, with particular reference to demand characteristics and their implications. A merican Psychologist, 17, 776-784.

Palmer, A. R. \& Strobeck, C. (1986). Fluctuating asymmetry: measurement, analysis, patterns. A nnual Review of Ecology and Systematics, 17, 391-421.

Payne, M . A . (1987). Impact of cultural pressures on self-reports of actual and approved hand use. Neuropsychologia, 25, 247-258.

Pelecanos, M . (1969). Some Greek data on handedness, hand clasping and arm folding. Human Biology, 41, 275-278.

Peters, M . (1986). Incidence of left-handed writers and the inverted writing position in a sample of 2194 German elementary school children. Neuropsychologia, 24, 429-433.

Peters, M. \& Perry, R. No link between left-handedness and maternal age or lefthandedness and accident rate. Neuropsychologia (in press).

Pipe, M . (1987). Pathological left-handedness: is it familial? Neuropsychologia, 25, $571-577$

Plato, C. C., Fox, K. M ., \& Garruto, R. M . (1984). M easures of lateral functional dominance: hand dominance. Human Biology, 56, 259-275.

Pool, R. (1991). Can lefties study be right? Nature, 350, 545-545.

Porac, C. \& Coren, S. (1979). A test of the validity of offsprings' report of parental handedness. Perceptual and M otor Skills, 49, 227-231. 
Porac, C. \& Coren, S. (1981d). L ateral preferences and human behaviour. N ew Y ork: Springer V erlag.

Porac, C., Coren, S., \& Searleman, A . (1983b). Inverted versus straight handwriting posture: a family study. Behavior Genetics, 13, 311-320.

Porac, C., Coren, S., \& Searleman, A . (1986c). Environmental factors in hand preference formation: evdence from attempts to switch the preferred hand. Behavior Genetics, $16,251-261$.

Porac, C., Izaak, M., \& Rees, L. (1990). A ge trends in handedness: an environmental approach. Paper presented at the meeting of the Canadian Psychological A ssociation, Ottawa, May 1990.

Porac, C., Rees, L., \& Buller, T. (1990c). Switching hands: a place for left hand use in a right hand world. In S.Coren (Ed.), Left-handedness: Behavioral implications and anomalies (pp. 259-290). A msterdam: N orth-Holland.

Provins, K. A . (1990). Handedness and conformity in a small isolated community. International Journal of Psychology, 25, 343-350.

Provins, K. A ., M ilner, A. D., \& Kerr, P. (1982c). A symmetry of manual preference and performance. Perceptual and M otor Skills, 54, 179-194.

Raczkowski, D., K alat, J. W., \& Nebes, R. (1974). Reliability and validity of some handedness questionnaire items. N europsychologia, 12, 43-47.

Ramal ey, F. (1913). Inheritance of left-handedness. A merican N aturalist, 47, 730-739.

Rhoads, J. G. \& Damon, A . (1973). Some genetic traits in Solomon Island populations: hand clasping, arm folding and handedness. A merican Journal of Physical A nthropology, 39, 179-184.

Rife, D. C. (1940). Handedness, with special reference to twins. Genetics, 25, 178-186.

Rife, D. C. \& Schonfield, M. D. (1944). A comparison of the frequencies of certain genetic traits among Gentile and J ewish students. Human Biology, 41, 172-180.

Roos, M. M. (1935). A study of some factors entering into the determination of handedness. Child Development, 6, 91-97.

Rosenthal, R. \& Rosnow, R. L. (1975). The volunteer subject. N ew Y ork: J ohn W iley. Rothman, K. J. (1991). Left-handedness and life expectancy. New England J ournal of Medicine, 325, 1041-1041. 
Rymar, K., Kameyama, T., Niwa, S.-I., Hiramatsu, K.-I., \& Saitoh, O. (1984). Hand and eye preference patterns in elementary and junior high school students. Cortex, 20, 441446.

Salmaso, D. \& Longoni, A . M . (1983a). Hand preference in an I talian sample. Perceptual and M otor Skills, 57, 1039-1042.

Salmaso, D. \& Longoni, A . M . (1985). Problems in the assessment of hand preference. Cortex, $21,533-549$.

Sanders, B., W ilson, J . R., \& V andenberg, S. G. (1982a). Handedness and spatial ability. Cortex, 18, 79-90.

Schacter, S. C., Ransil, B. J ., \& Geschwind, N. (1987). A ssociations of handedness with hair color and learning disabilities. Neuropsychologia, 25, 269-276.

Schwartz, M . (1977). L eft-handedness and high-risk pregnancy. Neuropsychologia, 15, 341-344.

Searleman, A., Porac, C., \& Coren, S. (1989). Relationship between birth order, birth stress, and lateral preferences: a critical review. Psychological Bulletin, 105, 397-408.

Searleman, A., T weedy, J., \& Springer, S. (1979b). Interrelationships among subject variables believed to predict cerebral organisation. B rain and Language, 7, 267-276.

Segal, N. L. (1984). Distribution of handedness among an academically select group of high school and university students. Journal of General Psychology, 111, 79-82.

Semenov, S. A . (1964). Prehistoric technology. Cory, M cA dams, and M acK ay.

Shimizu, A . \& Endo, M . (1983). Handedness and familial sinistrality in a Japanese student population. Cortex, 19, 265-272.

Silverberg, R., Obler, L. K ., \& Gordon, H. W . (1979). Handedness in Israel. Neuropsychologia, 17, 83-87.

Smith, J. (1987). Left-handedness: its association with allergic disease. Neuropsychologia, 25, 665-674.

Smith, L. G. (1917). A brief survey of right- and left-handedness. Pedagogical Seminary, 24, 19-35.

Soper, H. V . \& Satz, P. (1984). Pathological left-handedness and ambiguous handedness: a new explanatory model. Neuropsychologia, 22, 511-515.

Spenneman, D. R. (1984). Handedness data on the European N eolithic. Neuropsychologia, 22, 613-615. 
Spiegler, B. J . \& Y eni-Komshian, G. H. (1983). Incidence of left-handed writing in a college population with reference to family patterns of hand preference. Neuropsychologia, 21, 651-659.

Steenhuis, R. E. \& Bryden, M. P. (1989). Different dimensions of hand preference that relate to skilled and unskilled activities. Cortex, 25, 289-304.

Stei nmetz, H., V olkmann, J., J aencke, L., \& Freund, H.-J . (1991). A natomical left-right asymmetry of language-related temporal cortex is different in left- and right-handers. A nnals of Neurology, 29, 315-319.

Strang, J. (1991). Left-handedness and life expectancy. New England J ournal of Medicine, 325, 1041-1042.

Strauss, E. (1986). Hand, foot, eye and ear preferences and performance on a dichotic listening test. Cortex, 22, 475-482.

Tan, L. E. (1983). Handedness in two generations. Perceptual and M otor Skills, 56, 867-874.

Tan, L. E. \& Nettleton, N. C. (1980). Left handedness, birth order and birth stress. Cortex, 16, 363-373.

Tapley, S. M . \& Bryden, M. P. (1985). A group test for the assessment of performance between the hands. Neuropsychologia, 23, 215-221.

Teng, E. L., Lee, P.-H., Y ang, K.-S., \& Chang, P. C. (1979a). Lateral preferences for hand, foot and eye, and their lack of association with scholastic achievement, in 4143 Chinese. Neuropsychologia, 17, 41-48.

Teng, E. L., Lee, P., \& Chang, P. C. (1976a). Handedness in a Chinese population: biological, social and pathological factors. Science, 193, 1148-1150.

Toth, N. (1985). A rchaeological evidence for preferential right handedness in the lower and middle Pleistocene and its possible implications. Lournal of Human Evolution, 14, 607-614.

U guru-Okorie, D. C. \& A rbuthnott, G. W . (1981). A Itered paw preference after unilateral 6-hydroxydopamine inections into lateral hypothal amus. Neuropsychologia, 19, 463-467.

van Eys, P. P. \& M cK eever, W . F. (1988a). Subject knowledge of the experimenter's interest in handedness and familial sinistrality variables and laterality test outcomes. B rain and Cognition, 7, 324-334. 
Varney, N. R . \& Vilensky, J. A . (1980). Neuropsychological implications for preadaptation and language evolution. Lournal of Human Evolution, 9, 223-226.

Weller, M. P. I. \& Latimer-Sayer, D. T. (1985). Increasing right hand dominance with age on a motor skill task. Psychological M edicine, 15, 867-872.

Wolf, P. A., D'A gostino, R. B., \& Cobb, J. (1991). Left-handedness and life expectancy. New England J ournal of M edicine, 325, 1042-1042.

W ood, B. (1992b). Old bones match old stones. Nature, 355, 678-679.

Wood, B. (1992a). Origin and evolution of the genus H omo. Nature, 355, 783-790.

Woods, R. P., Dodrill, C. B., \& Ojemann, G. A . (1988). B rain injury, handedness and speech lateralization in a series of amobarbital studies. A nnals of N eurology, 23, 510-518. 